\title{
CLINICAL EFFICIENCY OF 2\% CHLORHEXIDINE GEL IN REDUCING INTRACANAL BACTERIA
}

\author{
Ching Shan Wang, DDS
}

A thesis submitted to the faculty of the University of North Carolina at Chapel Hill in partial fulfillment of the requirements for the degree of Master of Science in the School of Dentistry (Endodontics).

Chapel Hill

2007

Approved by:

Fabricio B. Teixeira, DDS, PhD

Martin Trope, DMD, MS

Roland R. Arnold. PhD

Eric Rivera, DDS, MS 
C)2007

Ching Shan Wang

ALL RIGHTS RESERVED 


\section{ABSTRACT \\ CHING S. WANG: Clinical Efficiency of 2\% Chlorhexidine Gel in Reducing Intracanal Bacteria. \\ (Under the direction of Dr. Fabricio B. Teixeira)}

This study evaluated the clinical efficacy of $2 \%$ chlorhexidine (CHX) gel on intracanal bacteria reduction during root canal instrumentation. The additional antibacterial effect of an intracanal dressing $\left(\mathrm{Ca}(\mathrm{OH})_{2}\right.$ mixed with $2 \% \mathrm{CHX}$ gel) was also assessed. Forty-three patients with apical periodontitis were recruited. Teeth were instrumented using rotary instruments and $2 \% \mathrm{CHX}$ gel as the disinfectant solution. Bacterial samples were taken upon access (S1), after instrumentation (S2), and following 2 weeks of intracanal dressing (S3). Anaerobic culture was performed. Of the samples cultured positively at S1, $10.3 \%(4 / 39)$ and $8.3 \%$ (4/36) sampled bacteria at S2 and S3, respectively. A significant difference in the percentage of positive culture between $\mathrm{S} 1$ and $\mathrm{S} 2(\mathrm{p}<0.001)$, but not between S2 and S3 (p=0.692), was found. These results suggest that $2 \% \mathrm{CHX}$ gel is an effective root canal disinfectant and additional intracanal dressing did not significantly improve the bacteria reduction on the sampled root canals. 


\section{ACKNOWLEDGMENT}

I would like to take this opportunity to recognize the following:

Dr. Fabricio B. Teixeira, my mentor, who always made time in his busy schedule to listen and help.

Dr. Martin Trope and Eric Rivera for their leadership, enthusiasm, and guidance over the past three years in my education and research.

Dr. Rolald Arnold for his insightful ideas and his vast knowledge of everything.

Eric Simmons for his help in the microbiology lab.

Jose Luis, Jason, Derek, Peter, and Anna, my co-residents. I will miss you next year.

Shu-Tang and Shu-Li Wang, my parents, who have always been there for me with love and encouragement.

Jeanne Wong, my girlfriend, who gave unconditional love and support for last 3 years. I love her very much. 


\section{TABLE OF CONTENTS}

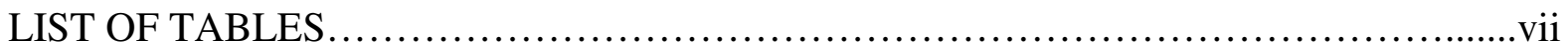

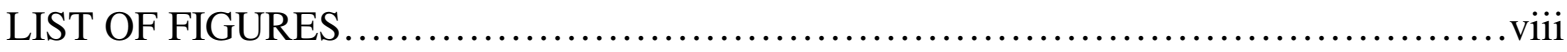

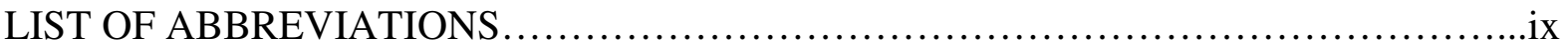

Chapter

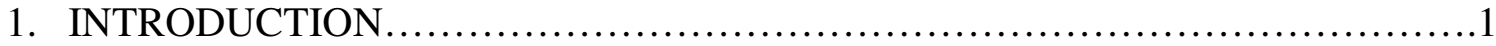

a. Apical Periodontitis.................................................

b. Endodontic Therapy..................................................

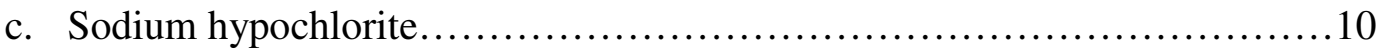

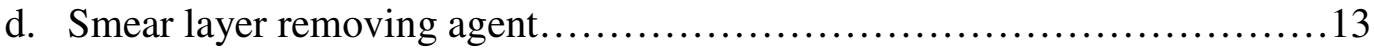

e. Calcium hydroxide.................................................... 15

f. Chlorhexidine....................................................... 16

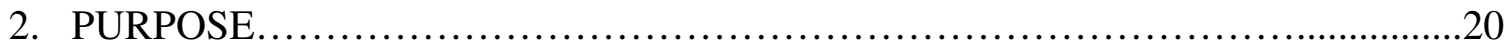

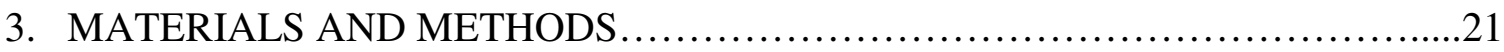

a. In Vitro Evaluation of 2\% CHX Gel Neutralizer.........................21

b. Subject Recruitment and Qualification........................................23

c. Treatment Group Assignment......................................24

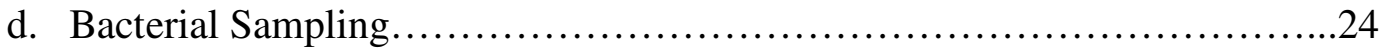

e. Data Analysis....................................................28 


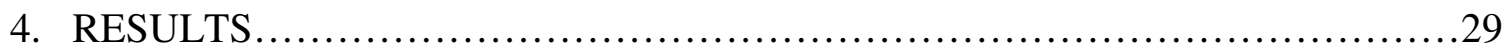

a. In Vitro Evaluation of 2\% CHX Gel Neutralizer..........................29

b. In Vivo Evaluation of the Clinical Efficacy of $2 \%$ CHX Gel................29

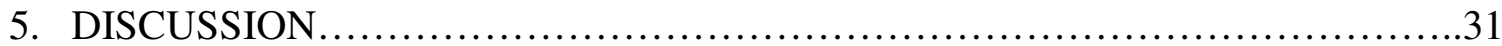

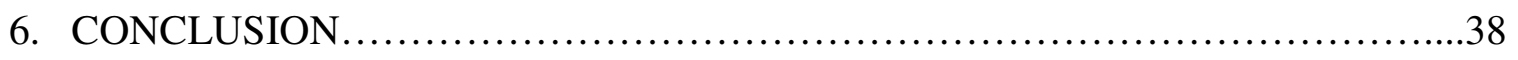

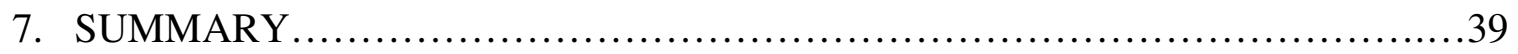

APPENDIX I: Informed consent example.......................................41

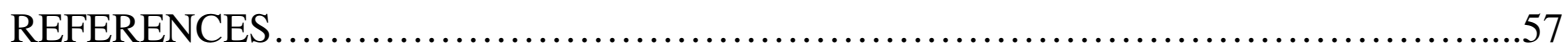




\section{LIST OF TABLES}

Table

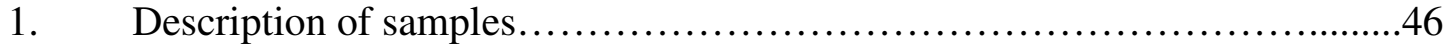

2. Apical preparation size corresponding to canal and tooth type...............46

3. CFU counts for each sample.....................................47

4. Percentage of samples with negative culture............................48 


\section{LIST OF FIGURES}

Figure

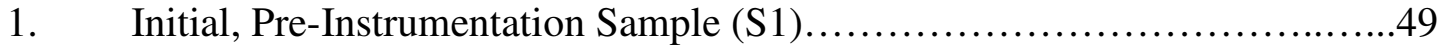

2. Post-Instrumentation Sample (S2) .................................. 50

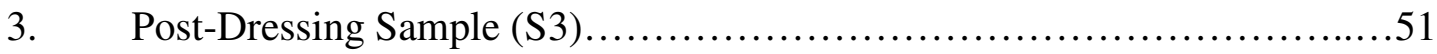

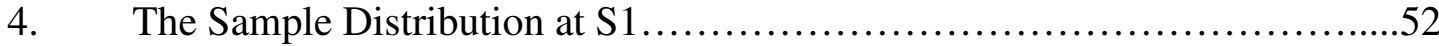

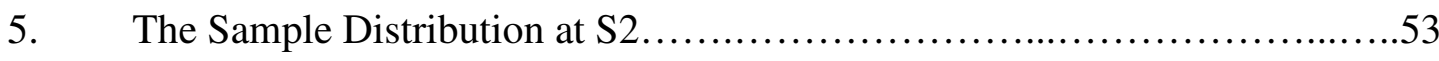

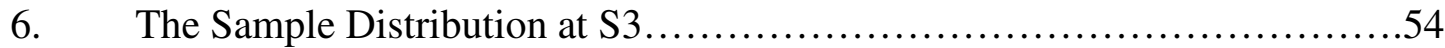

7. Percentage of samples with positive culture..............................55

8. Comparison of percentage of canals with positive culture at different culturing points from selected studies.................................56 


\section{ABBREVIATIONS}

$\begin{array}{ll}\mathrm{Ca}(\mathrm{OH})_{2} & \text { Calcium Hydroxide } \\ \mathrm{CHX} & \text { Chlorhexidine } \\ \mathrm{CFU} & \text { Colony Forming Unit } \\ \text { EDTA } & \text { Disodium ethylendiamine-tetraacetate } \\ \mathrm{NaOCl} & \text { Sodium Hypochlorite } \\ \mathrm{NiTi} & \text { Nickel-Titanium } \\ \text { SS } & \text { Stainless-Steel } \\ \text { RPM } & \text { Revolutions Per Minute } \\ \text { LDTM } & \text { Liquid Dental Transport Medium }\end{array}$




\section{CHAPTER 1 \\ INTRODUCTION}

\section{1a. Apical Periodontitis}

Apical periodontitis is an inflammatory process on the periradicular tissues caused by the microbes presented inside root canal system (Kakehasi et al. 1965, Sundqvist 1976, Möller et al. 1981, Fabricius et al. 1982a). It is essentially the body's defense response to the damage of the pulpal tissue and microbial infection of the root canal system.

Research in the past three decades has established the essential role of microorganisms in the pathogenesis of apical periodontitis. As early as in later 1890, Miller demonstrated the presence of bacteria in necrotic pulp. Later, Kakehasi et al. (1965) showed that no apical periodontitis developed in germ-free rats when their molar-pulps were kept exposed to the oral cavity, as compared with control rats with a conventional oral microflora in which massive periapical radiolucencies occurred. Möller et al. (1981) demonstrated that the bacteria, not the necrotic pulp tissue, was the etiology for periapical inflammation in his monkey study. Sundqvist (1976) investigated previously traumatized teeth with necrotic pulp. The study showed that 18 out of 19 teeth with radiographic sign of apical periodontitis had cultivable bacteria; whereas, no bacteria could be isolated from the root canal of teeth without apical periodontitis. Bacterial species were predominately obligate anaerobes including Fusobacterium, Porphyromonas (formerly Bacteroides), Prevotella (formerly 
Bacteroides), Eubacterium, Peptococcus, Peptostreptococcus and Camylobacter. Baumgartner and Falkler (1991) demonstrated that teeth with carious pulpal exposures and periapical lesions were predominately colonized by anaerobic bacteria in the apical $5 \mathrm{~mm}$.

The endodontic environment provides a selective environment for establishment of a mixed root canal flora. It is predominated by Gram-negative anaerobic bacteria, due to the lack of oxygen and the availability of host tissues and tissue fluids as the primary nutrient source (Sundqvist et al. 1992). In a monkey study, Fabricius et al. (1982a) inoculated indigenous oral flora into root canal system and sealed the canals for a period of 1080 days. In the early stage, the root canal flora was predominately colonized by facultative bacteria. Shortly, strict anaerobes displaced the facultative bacteria. After 1080 days, 98\% of bacteria isolated from the root canal system were strict anaerobes. In another study, Fabricius et al. (1982b) showed the mixed infections had the greatest capacity to induce apical periodontitis. He studied the ability of 11 bacterial strains, in various combinations, to induce periapical reaction in a monkey model. Other than Enterococcus, all other strains cannot survive as pure culture in the root canal system. The facultative anaerobe identified in most samples can only induce weak periapical reaction, while the combination of facultative and strict anaerobes can induce profound periapical inflammation. Based on those studies, it appeared there is selective pressure by the endodontic environment that favors the survival of strict anaerobes. In addition, certain combinations of bacteria are required to induce apical periodontitis, suggesting positive, mutually supportive, as well as negative interactions between bacterial species.

Bacteria can potentially penetrate dentinal tubules and protect themselves from the mechanical and chemical destruction during the root canal therapy. Ando and Hoshino 
(1990) demonstrated the presence of bacteria 500 to $2000 \mu \mathrm{m}$ in dentinal tubules in carious human teeth by light microscopy. Love et al. (1996) showed bacteria invaded and penetrated deeper in cervical and mid root than the apical root. In some case, bacteria can potentially penetrate nearly to the cementum layer of the roots in teeth with apical periodontitis (Peters et al. 2001). Matsuo et al. (2003) also demonstrated that $70 \%$ of tubules had bacteria penetrated up to cementum using immunohistochemistry methods.

Bacterial species found in the dentinal tubules are similar to those found in the main root canal system. Ando and Hoshino (1990) showed the predominate bacteria found in the dentinal tubules was Lactobacillus, Streptococcus, Propionibacterium, and Peptostreptococcus. Matsuo et al. (2003) showed the presence of Fusobacterium, Eubacterium, Lactobacillus and Peptostreptococcus in the dentinal tubules.

Due to the anatomic restriction, bacteria in the tubules are difficult to remove by instrumentation and irrigation. Even with intracanal medications, viable bacteria were found in infected human dentin tubules after the treatment (Weiger et al. 2002). Although the clinical significance of bacteria in dentinal tubules is still not clear, studies tend to agree that the remaining bacteria in the tubules after the root canal treatment can contribute to failure of endodontic therapy (Love and Jenkinson 2002, Oguntebi et al. 1994, Peters et al. 2001).

In addition to bacteria, fungi and viruses were also detected in the infected root canal system. In teeth with apical periodontitis, the presence of fungi has been demonstrated in dentinal tubules (Sen et al. 1995), failing root canal treatment (Molander et al. 1998), and in periapical tissues (Tronstad et al. 1987). Prevalence of fungi in infected root canal system ranges from $0.5 \%$ to $26 \%$ in untreated root canals (Baumgartner et al. 2000) and $3.7 \%$ to $33 \%$ in cases of failed root canal treatment (Molander et al. 1998, Waltimo et al. 1997). 
Most commonly isolated fungus is Candida albicans (Waltimo et al. 1997). At present, the role of fungi in the pathogenesis of endodontic diseases is still not clear. Similarly, the presence of virus in the infected root canal system has only shown in case reports (Glick et al.1989) and their role in the development of apical lesion is not known.

Taken together, studies strongly support the primary role of bacteria in the development of apical periodontitis and the infected root canal flora is polymicrobial and predominately anaerobic.

\section{1b. Endodontic Therapy}

The goal of endodontic treatment is to prevent and eliminate apical periodontitis. This objective is accomplished through disinfection of the root canal space and adequate root canal filling to prevent recontamination. The endodontic treatment protocol should be based on sound biologic rationale for more effective clinical management of the disease.

Long-term endodontic success for the teeth with apical periodontitis ranges from $75 \%$ to $90 \%$ (Stringberg et al. 1956, Kerekes and Tronstand 1979, Byström et al. 1987, Sjogren et al. 1990, Trope et al. 1999, Weiger et al. 2000, Peters \& Wesslink 2002) with functional success rate of 95\% (Byström et al. 1987, Weiger et al. 2000, Peters \& Wesslink 2002). Endodontic success (healed) is defined as the absence of clinical symptoms and radiographic resolution of periapical lesion (Stringberg et al. 1956).

In a retrospective study with 6-month to 5-year follow-up, 478 teeth endodontically treated by undergraduate students were evaluated (Kerekes and Tronstand 1979). Overall success rate (both vital and non-vital cases) was $83 \%$ at first year, then, increased to $91 \%$ at 3-5 year follow-up. In cases of apical periodontitis, the success rate was $85 \%$. Other 
retrospective studies also demonstrated similar success rate for the teeth with apical periodontitis. Stringberg et al. (1956) showed $80 \%$ healed at 6-month to 10-year follow-up. Sjögren et al. (1990) had 86\% success rate with 8-10 year follow-up period. Toronto study (Farzaneh et al. 2004) showed 79\% success rate at 4-6 year follow-up.

Prospective studies also showed comparable success rate. Sjögren et al. (1997) examined the 5-year outcome study on 53 single-rooted anterior teeth with radiographic periapical lesion. Overall success rate was 83\%. In another prospective study, 79 endodontically treated teeth with apical periodontitis were followed up for 2 to 5 years (Byström et al. 1987). Eighty five percent (85\%) of the cases were healed completely and $9 \%$ of the cases were healing, with functional success rate of $94 \%$. In agreement with this finding, other studies also showed about $95 \%$ functional success rate for endodontically treated teeth (Weiger et al. 2000, Peters \& Wesslnik 2002).

In contrast to the university-based study, cross-sectional studies showed much lower success rate. Buckely and Spangberg (1995) assessed the prevalence of radiographically detectable periapical disease and its relationship to the quality of endodontic care in a North American population. The authors examined 208 randomly chosen full-mouth $\mathrm{x}$-ray (FMX) series with 5,272 teeth taken at the initial screening. They found $31.3 \%$ of root canal filled teeth had periapical disease and only in about $40 \%$ of cases was technically satisfactory root canal treatment achieved. Similarly, Ray and Trope (1995) evaluated 1,010 endodontically treated teeth from FMX series with minimal of 1 year follow-up. Overall, they found $61 \%$ of the teeth had no radiographic sign of apical periodontitis. Lower success rate observed in cross-sectional studies is likely due to the poor quality of endodontic care performed in private practice setting. 
Long term success of endodontic therapy depends on many factors including tooth vitality, level of root-canal disinfection, length and quality of root canal filling, and coronal restoration (Stoll et al. 2005, Schaeffer et al. 2005, Caplan \& Weintraub 1997, Sorensen et al. 1984, 1985, Vire et al. 1991, Aquilino \& Caplan 2002, Ray \& Trope 1995).

Outcome studies of root canal treatment consistently showed higher long-term success rate for the teeth without apical periodontitis than the teeth with apical periodontitis (Sjögren et al. 1990, Kerekes \& Tronstad 1979, Stringberg et al. 1956, Stoll et al. 2005). Teeth with vital pulp have long-term success rates of $95-97 \%$, while teeth with apical periodontitis range from 75\% to 90\% (Stringberg et al. 1956, Kerekes and Tronstand 1979, Byström et al. 1987, Sjögren et al 1990, Trope et al. 1999, Weiger et al. 2000, Peters \& Wesslink 2002). The observed difference in the outcome between these two groups is due to the ability of operators to disinfect root canal system. In case of vital pulp, root canal space is not infected with microorganism but filled with inflamed pulp tissue (Seltzer and Bender 1963, Mumford et al. 1967, Dummer et al. 1980). Hence, it is more likely to achieve a root canal space free of bacteria assuming the treatment is performed under strict aseptic protocol. On the other hand, teeth with apical periodontitis are usually associated with necrotic pulp infected with obligate and facultative bacteria (Sundqvist 1976, Möller et al. 1981, Fabricius et al. 1981). In such case, complete elimination of bacteria from the root canal space is limited due to the complexity of root canal anatomy and resistant bacteria.

Sjögren et al. (1997) investigated the role of infection on the prognosis of endodontic therapy by following-up teeth that had their canals cleaned and obturated during a single appointment. In this study, the root canals of 55 single rooted teeth with apical periodontitis were thoroughly instrumented and irrigated with $\mathrm{NaOCl}$ solution. Periapical healing was 
followed up for 5 years. Complete healing occurred in $94 \%$ of cases that yielded negative culture. Where the samples were positive prior to root filling, the success rate of treatment was just 68\%. Byström et al. (1987) also demonstrated $95 \%$ healing when the root canal filled after the negative culture. Other studies also demonstrated similar results (Zeldow \& Ingle 1963, Engström et al. 1964). Hence, the presence of bacteria prior to root canal filling is a negative predictor for the long term success of root canal treatment.

Root canal disinfection can be accomplished by mechanical and chemical means. Mechanical microbial control phase involves root canal instrumentation using hand and/or rotary instruments. In contrast, chemical microbial control phase involves antimicrobial agents during and after instrumentation.

Mechanical instrumentation can reduce intra-canal bacteria significantly but can not predictably eradicate them. Byström and Sundqvist (1981) evaluated the efficacy of the mechanical instrumentation in bacterial reduction during root canal treatment. Fifteen singlerooted teeth with apical periodontitis were treated in five visits with no inter-appointment dressing. Root canals were instrumented with hand files and with physiological saline as irrigant. Mechanical instrumentation with saline reduced the number of bacteria significantly, by 100-1000 fold. However, despite being treated 5 times, bacteria can not be predictably eliminated from the root canal system. They also showed that $0.5 \% \mathrm{NaOCl}$ was more effective than physiological saline when used as irrigant. Other studies also support this finding (Siqueira et al. 2000, Byström \& Sundqvist 1985, Dalton et al. 1998, Shuping et al. 2000)

On average, $40 \%$ - $60 \%$ of root canals have no cultivable bacteria after mechanical root canal instrumentation with $\mathrm{NaOCl}$ solution (Dalton et al. 1999, Shuping et al. 2001, 
Card et al. 2002, McGurkin-Smith et al. 2005, Kvist et al. 2004). Shuping et al. (2000) evaluated the extent of bacterial reduction with NiTi rotary instrumentation and $1.25 \%$ $\mathrm{NaOCl}$ irrigation in 42 patients with apical periodontitis. Bacterial samples were taken before and after the instrumentation, and they were cultured anaerobically for 7 days. The authors found $62 \%$ of canals were rendered bacteria-free after instrumentation with $1.5 \%$ $\mathrm{NaOCl}$. McGurkin-Smith et al. (2005) obtained $40 \%$ of canals sampled bacteria free after instrumentation and a strict irrigation protocol using $5.25 \% \mathrm{NaOCl}$ and EDTA.

Another method to improve root canal disinfection is to enlarge the apical preparation (Dalton et al. 1999, Siqueira et al. 1999, Shuping et al. 2000, Card et al. 2002, Baugh \& Wallace 2005). Dalton et al. (1999) demonstrated that regardless of technique (hand file or rotary file), uniform reduction of bacteria occurred with progressive filing. Siqueira et al. (1999) showed the same result from in vitro study. In a clinical study, Card (2002) was able to demonstrate $100 \%$ of canine and premolar, and $89 \%$ of molars rendered bacteria free after preparing apical size to \#60 and \#80 using LightSpeed instruments. In additional to mechanical reduction of bacteria, apical enlargement also allows better access for the irrigant to reach the apical region and disinfect the bacterial contents (Shuping et al. 2000, Salzgeber et al. 1977, Ram et al. 1977, Chow et al. 1983, Siqueira et al. 1999). Studies have shown that canals need to be enlarged to at least \#35 file for adequate irrigation to reach apical third. Ram et al. (1977) concluded that canals need to be enlarged to a $\# 40$ file size so that maximum irrigation is in contact with the apical debris. Chow et al. (1983) also showed the canal system had to be instrumented to at least \#40 file for proper irrigation. Shuping et al. (2000) and Siqueira et al. (1999) later confirmed the findings that $\mathrm{NaOCl}$ requires a certain size canal to become beneficial in bacterial reduction. 
Nonetheless, eradication of endodontic infection by instrumentation and $\mathrm{NaOCl}$ solution alone is limited (Byström\& Sundqvist 1981, 1985, Sjögren et al. 1991, Dalton et al.1999, Shuping et al. 2000, Card et al. 2002). To obtain a more predictable microbial control, placement of intracanal medicaments such as calcium hydroxide $\left(\mathrm{Ca}(\mathrm{OH})_{2}\right)$ is recommended (Ørstavik et al. 1991, Shuping et al. 2000, Sjogren et al. 1991). Intracanal medicaments are used to: (a) eliminate bacteria in the root canal; (b) prevent bacterial proliferation between appointments; and (c) act as a physicochemical barrier, preventing root-canal reinfection and nutrient supply to the remaining bacteria (Byström \& Sundqvist 1985). Calcium hydroxide is one of most widely used intracanal medications in endodontics today and remains the best medicament available to reduce residual microbial flora (Law et al. 2004). It is a strong alkaline substance, which has a $\mathrm{pH}$ of approximately 12.5 . In an aqueous solution, calcium hydroxide dissociates into calcium and hydroxyl ions that will lead to a lowered oxygen tension and an increase in the $\mathrm{pH}$ in the inflamed periapical tissues (Siqueira et al. 1999). With a high $\mathrm{pH}$, calcium hydroxide has an excellent broad antimicrobial effect.

To support this, studies consistently demonstrated that $\mathrm{Ca}(\mathrm{OH})_{2}$ can help to further eliminate surviving bacteria in the root canals. Sjögren et al. (14) showed that bacteria were not found in teeth with apical periodontitis dressed with $\mathrm{Ca}(\mathrm{OH})_{2}$ for 1 wk. Ørstavik et al. (1991) demonstrated that extensive apical reaming and 1 week dressing with $\mathrm{Ca}(\mathrm{OH})_{2}$ significantly reduced bacterial growth from root canal and apical dentin samples. Shuping et al. (2000) showed that placement of $\mathrm{Ca}(\mathrm{OH})_{2}$ for at least 1 week rendered $92.5 \%$ of canals bacteria free in teeth with apical periodontitis. Law et al. (2004) reviewed the literature evaluating the antibacterial effectiveness of $\mathrm{Ca}(\mathrm{OH})_{2}$ used in the management of apical 
periodontitis and found $27 \%$ of canals showed detectable bacteria growth after medication. However, $\mathrm{Ca}(\mathrm{OH})_{2}$ has been shown to be ineffective when used as a short-term dressing $(<1$ d) (Sjögren et al. 1991, Safavi et al. 1990) and requires at least 1 week to properly exert its antibacterial action. Thus, a minimum of two-visit root canal treatment is strongly recommended for adequate intracanal disinfection in cases of apical periodontitis (Trope et al. 1991).

\section{1c. Sodium Hypochlorite ( $\mathrm{NaOCl})$}

Sodium hypochlorite was first recommended as an antiseptic solution by Henry Dakin (1915) to irrigate open wounds during World War I. Later, Coolidge (1919) introduced $\mathrm{NaOCl}$ to endodontics and it has remained the most used irrigant.

$\mathrm{NaOCl}$ has several characteristics that make this solution a desirable endodontic irrigant, including its antimicrobial (Byström \& Sundqvist, 1983, 1985, Siqueira et al. 2000, Zehnder et al. 2002), tissue dissolving (Thé et al. 1980, Moorer \& Wesselink1982, Zehnder et al. 2002) and lubricating properties.

$\mathrm{NaOCl}$ has a broad-spectrum antimicrobial activity (Byström \& Sundqvist 1983). It can kill vegetative bacteria, spore-forming bacteria, fungi, protozoa, and viruses (Rutala \& Weber 1997). Effectiveness of $\mathrm{NaOCl}$ as intracanal antimicrobial agent has been well documented.

There have been conflicting results concerning the antimicrobial efficacy of different $\mathrm{NaOCl}$ concentrations. In general, in vitro studies (Siqueira et al. 1998, Yesilsoy et al. 1995) showed that $5.25 \% \mathrm{NaOCl}$ is more effective than lower concentration solution in eliminating bacteria. In contrast, clinical studies found no difference in the antimicrobial effect between

$0.5 \%$ and $5 \% \mathrm{NaOCl}$ (Byström \& Sundqvist 1985, Cvek et al. 1976). This disparity between 
in vitro and clinical studies is likely attributable to the differences in methodology. In vitro studies for testing antimicrobial properties of a solution are often carried out in test tubes or agar plates, which do not take into consideration of root canal complexity. To eliminate bacterial cells within the root canal system, irrigants must be able to reach them. Many areas in the root canal system have the potential to harbor microorganisms, thus making them inaccessible to the effects of chemomechanical preparation. In case of using weaker $\mathrm{NaOCl}$ solution, many authors recommended frequent replenishing of the irrigants in order to compensate for the quick neutralization of $\mathrm{NaOCl}$ (Byström \& Sundqvist 1985, Siqueira et al. 2000).

The tissue dissolving ability of $\mathrm{NaOCl}$ has been well investigated. Grossman and Meiman (1941) showed that chlorinated soda (solution containing $\mathrm{NaOCl}$ and $\mathrm{NaCl}$ ) was an effective solvent of pulp tissue in an in vitro study. It was found to dissolve the pulps of freshly extracted teeth in less than 24 hours. Since then, numerous studies have been published on the tissue dissolution property of $\mathrm{NaOCl}$ when used as endodontic irrigant (Moorer \& Wesselink 1982, Thé et al. 1979, Zender et al. 2002). There are several factors thought to be important for the efficacy of $\mathrm{NaOCl}$ irrigant in dissolving pulp tissue. In an in vitro study, Moorer \& Wesselink (1982) investigated the effect of fluid flow, $\mathrm{pH}$ and available surface area of tissue on the tissue dissolving capability of $\mathrm{NaOCl}$. The authors concluded that the tissue-dissolving power of $\mathrm{NaOCl}$ solution appeared to be strongly depended on (1) the amount of organic matter in the hypochlorite/tissue system (2) the frequency and intensity of mechanical agitation (fluid flow) and (3) the available surface area of free or enclosed tissue. For hypochlorite solution to be effective, it should act quickly and be in an excess in relation to the amount of organic material that was to be digested. In 
addition, the authors suggested that it was the amount of $\mathrm{NaOCl}$ that was important for the tissue dissolution rather than the concentration. Hence, they recommend the continuous and intensive mechanical debridement of the canal system and repeated refreshment of the $\mathrm{NaOCl}$. These authors also showed the importance of mechanical agitation on tissue dissolving ability of $\mathrm{NaOCl}$, particularly ultrasonic agitation shown to be very effective.

Although higher concentrations of $\mathrm{NaOCl}$ show more effective tissue dissolving properties on a fixed surface area (Zehnder et al. 2002, Moorer \& Wesselink 1982), it is not true when there are only small amounts of tissue (Moorer \& Wesselink 1982). Baumgartner and Cuenin (1992) showed that $\mathrm{NaOCl}$ in concentration of $1 \%, 2.5 \%$, and $5.25 \%$ completely removed pulpal remnants and predentin from uninstrumented dentinal walls. Thus it appears that low concentration of $\mathrm{NaOCl}$ retains adequate tissue dissolving and antibacterial properties.

Cytotoxicity of $\mathrm{NaOCl}$ is a major disadvantage for its clinical use. Pashley et al. (1985) had tested the cytotoxicity of various dilutions of sodium hypochlorite on 3 independent biological models (hemolysis of RBC, rabbit eye experiments, and intradermal injections). All dilution caused hemolysis, moderate to severe irritation to rabbit eyes, and skin ulcertation. It was found that higher concentration $\mathrm{NaOCl}$ causes more cytotoxic effects on the vital tissue. The authors concluded that $5 \% \mathrm{NaOCl}$ must be used judiciously and with great caution to prevent it from reaching the periapex where it could elicit severe inflammatory reactions. Spangberg et al. (1973) suggested that $5.25 \% \mathrm{NaOCl}$ was considerably stronger than necessary to eliminate bacterial strains commonly found in infected root canals. At this concentration, the author believed $\mathrm{NaOCl}$ was considered too cytotoxic to be routinely used in endodontic therapy. 
Taken together, low concentration of $\mathrm{NaOCl}$ is sufficient to dissolve pulp tissue and eliminate bacteria in the root canal system. Clinical use of full-strength $\mathrm{NaOCl}$ should be avoided due to its strong cytotoxicity.

\section{1d. Smear Layer Removing Agents}

Current methods of root canal instrumentation produce a smear layer on the surface of canal walls (McComb \& Smith 1975, Goldman et al. 1988, Yamada et al. 1983, Torabinejad et al. 2002). Under Scanning Electronic Microscopy (SEM), this layer has amorphous, irregular, and granular appearance that can penetrate into and occlude the dentinal tubules (McComb \& Smith 1975). It contains both inorganic and organic substances that include dentine, remnant of pulp tissue, odontoblastic processes, and microorganisms (Torabinejad et al. 2002).

In infected root canals, bacteria, predominantly Gram-negative anaerobes, can be identified from the root canal system and in the dentinal tubules (Ando \& Hoshino 1990, Sen et al. 1995, Love \& Jenkinson 2002). Viable bacteria were isolated from the infected dentinal tubules of root canal system in extracted human teeth (Peters et al. 2001). Histological and SEM studies showed bacteria can penetrate into the dentinal tubules at various distances from the surface of root canal wall (Ando \& Hoshino 1990, Sen et al. 1995, Peters et al. 2001). In some case, bacteria can potentially penetrate to the cementum layer (Peters et al. 2001). Under in vitro conditions, several investigators have successfully infected the dentinal tubules with microorganisms (Haapasalo \& Ørstavik 1987, Siqueira et al. 1996, Perez et al. 1993). Hence the available evidence strongly suggests that viable bacteria can invade the dentinal tubule during root canal infection process. 
The presence of smear layer after root canal instrumentation raises some concerns. Several investigators have found that the smear layer itself may be infected and may protect bacteria already in the dentinal tubules (McComb \& Smith 1975, Haapasalo \& Ørstavik 1987). It has been shown that the smear layer is not a complete barrier to bacteria and it delays but does not abolish the action of endodontic disinfectants (Ørstavik \& Haapasalo 1990). Clinically, whether bacteria in the dentinal tubule can be predictably eliminated by the disinfectants, in the presence of smear layer, is questionable. The remaining viable bacteria in the dentinal tubule may be responsible for the persistent endodontic infection after root canal therapy (Stuart et al. 2006). Hence, it is prudent to remove the initially created smear layer in infected root canals and to allow penetration of endodontic disinfectants into the dentinal tubule more effectively (Torabinejad et al 2002).

The smear layer of root canal walls also act as a physical barrier interfering with adhesion and penetration of sealers into dentinal tubules (Abramovich \& Goldberg 1976, Tidmarsh 1978, White et al. 1984). Studies have shown that root canal sealers can penetrate into dentinal tubules in the absence of smear layer; whereas, no penetration was observed with the smear layer intact (Gutiérrez et al. 1990, Pallarés et al. 1995, Kouvas et al. 1998). This characteristic is particularly important for some root canal filling materials such as Resilon (Shipper et al. 2004) and many other resin-based sealers. Removal of smear layer prior to root canal filling has also shown to reduce microleakage (Pashley \& Depew 1986, Taylor et al. 1997, Timpawat et al. 2001).

EDTA (Ethylenediaminetetracetic acid) is a chelating agent, commonly used for removal of smear layer from the instrumented root canal walls (McComb \& Smith 1975, Yamada et al. 1983, Baumgartner \& Mader 1987). Since smear layer is composed of both 
organic and inorganic materials, the combination of EDTA and sodium hypochlorite $(\mathrm{NaOCl})$ is often recommended (Goldman et al. 1988, Yamada et al. 1983, Baumgartner \& Mader 1987). In addition to EDTA, citric acid can also be used (Baumgartner et al. 1984). Recently, new solutions have been proposed with enhanced antimicrobial properties in addition to their smear layer removal ability such as Biopure ${ }^{\mathrm{TM}}$ MTAD (Torabinejad 2003a, Torabinejad 2003b) and SmearClear ${ }^{\mathrm{TM}}$. Although their abilities to remove smear layer are well demonstrated, antimicrobial efficiency of Biopure ${ }^{\mathrm{TM}}$ MTAD has been questioned (Kho and Baumgartner 2006, Baumgartner et al. 2007)

\section{1e. Calcium hydroxide $\left(\mathrm{Ca}(\mathrm{OH})_{2}\right)$}

Calcium hydroxide was introduced in endodontic therapy by Hermann in 1920 and often recommended for disinfection of the root canal space in teeth with apical periodontitis.

The effectiveness of interappointment $\mathrm{Ca}(\mathrm{OH})_{2}$ has been well investigated. Byström et al. (1985) reported that $\mathrm{Ca}(\mathrm{OH})_{2}$ was an effective intracanal medicament rendering 34 out of 35 canals bacteria free after 4 weeks. Sjögren et al. (1991) who demonstrated that a 7-day dressing with $\mathrm{Ca}(\mathrm{OH})_{2}$ eliminated all bacteria in the root canal but it is ineffective when used for short-term. Shuping et al. (2000) also demonstrated the effectiveness of $\mathrm{Ca}(\mathrm{OH})_{2}$ as root canal disinfectant when used for $>1$ week.

Even though $\mathrm{Ca}(\mathrm{OH})_{2}$ is a good antimicrobial agent, it is ineffective against some of microorganisms such as Enterococcus faecalis (Sjögren et al. 1991, Haapasalo and Ørstavik 1987, Heling et al. 1992), which is found in the case of persistent root canal infection. Byström et al. (1985) showed the most resistant strain to $\mathrm{Ca}(\mathrm{OH})_{2}$ belonged to the genus Enterococcus, which can survive at $\mathrm{pH} 11.5$, but not at $\mathrm{pH} 12.5$. In addition, some studies 
have questioned the effectiveness of $\mathrm{Ca}(\mathrm{OH})_{2}$ to disinfect the canal and reported a residual flora in the canal after one or more weeks with $\mathrm{Ca}(\mathrm{OH})_{2}$ (Reit et al.1999, Peters et al. 2002, Kvist et al. 2004, Waltimo et al. 2005). Hence, it is necessary to explore new antimicrobial agents that are effective in eliminating intracanal microorganisms including facultative microorganisms such as E. faecalis.

\section{1f. Chlorhexidine (CHX)}

Despite the fact that $\mathrm{NaOCl}$ eradicates bacteria effectively, it is caustic if accidentally expressed into the periapical area or adjacent structures (Hülsmann and Hahn 2000). In addition, it has strong bleaching effect and foul odor. Chlorhexidine (CHX) gluconate has been suggested as an alternative irrigating solution that could replace $\mathrm{NaOCl}$.

$\mathrm{CHX}$ is one of the most widely used biocides in antiseptic products in general. It is a cationic bisguanide that seems to act by adsorbing onto the cell wall of microorganism and cause leakage of intracellular components. At low concentration, it has bacteriostatic effect. While at high concentration, it is bactericidal due to precipitation and/or coagulation of intracellular constituents (Mcdonnell and Russell 1999). Its optimal antimicrobial activity is at pH 5.5-7.0 (Russell and Day 1993).

CHX gluconate has been in use for a long time in dentistry. It has a broad spectrum antimicrobial activity, targeting both Gram positive and Gram negative bacteria (Delany et al. 1982, Ringel et al. 1982, Jeansonne \& White 1994). In general, in vitro studies suggested that $\mathrm{CHX}$ and $\mathrm{NaOCl}$ have comparable antibacterial effect when used in similar concentration (Jeansonne \& White 1994, Estrela et al. 2003, Vianna et al. 2004). Jeansonne and White (1994) compared the antimicrobial activity of $2.0 \% \mathrm{CHX}$ gluconate with that of 
$5.25 \% \mathrm{NaOCl}$ in an in vitro root canal system. Microbiological samples were taken before and after instrumentation with each endodontic irrigant. The number of positive cultures and colony-forming units after instrumentation were lower in $\mathrm{CHX}$-treated than $\mathrm{NaOCl}$-treated teeth, but the differences were not statistically significant. Estrela et al. (2003) tested the minimum inhibitory concentration and antimicrobial effectiveness by the direct exposure of endodontic irrigants for microbes commonly isolated from the infected root canal system and found that $2 \% \mathrm{CHX}$ and $5.25 \% \mathrm{NaOCl}$ had similar antimicrobial activity against those organisms. Vianna et al. (2004) showed the time required for $1.0 \%$ and $2.0 \%$ CHX liquid to eliminate Staphylococcus aureus, Candida albicans, E. faecalis, Prevotella endodontalis, Porphyromonas gingivalis, and Prevotella intermedia, was the same as required for 5.25\% $\mathrm{NaOCl}$.

In addition to its antimicrobial property, $\mathrm{CHX}$ has substantivity in root canal dentin (Basrani et al. 2002, Rosenthal et al. 2004, Dametto et al. 2005). Rosenthal et al. (2004) investigated the substantivity of $\mathrm{CHX}$ in bovine roots. Roots with standardized length were instrumented with $1 \%$ sodium hypochlorite and EDTA followed by placing in $2 \% \mathrm{CHX}$ solution for 10 minutes prior to obturation. After a certain period, all specimens were halved and canal wall dentin was ground out with Peeso reamers followed by mixing the dentin debris with E. faecalis in a test tube. It was shown that $\mathrm{CHX}$ can be retained in root canal dentin in antimicrobial effective amounts for up to 12 weeks. Other studies also demonstrated the substantivity of CHX in rood canal dentin (Basrani et al. 2002, Dametto et al. 2005).

The relatively low toxicity of CHX is an additional advantage. Filho et al. (2002) evaluated the inflammatory response to irrigation solutions $(0.5 \% \mathrm{NaOCl}$ and $2 \% \mathrm{CHX})$ 
injected into the peritoneal cavity of mice. They demonstrated $0.5 \% \mathrm{NaOCl}$ solution induced inflammatory response while $2 \% \mathrm{CHX}$ solution did not induce a significant inflammatory response. In a recent study, Dammaschke et al. (2005) assessed the effects of 2\% CHX gel and calcium hydroxide on apical periodontitis in Wistar rats. The investigators showed that CHX gel used as intra-canal medicament led to good periapical regeneration, suggesting that this may be an alternative to calcium hydroxide root canal dressing.

Despite the advantages of $\mathrm{CHX}$, its activity is $\mathrm{pH}$ dependent and is greatly reduced in the presence of organic matter (Russell and Day 1993). Unlike sodium hypochlorite, it lacks tissue dissolving properties (Naenni et al. 2004).

2\% $\mathrm{CHX}$ in a gel formulation (Endogel, Itapetininga, SP, Brazil) was proposed as an alternative to $5.25 \% \mathrm{NaOCl}$ solution for root canal disinfection (Ferraz et al. 2001). This lubricant is composed of a gel base (1\% natrosol) which is a nonionic, highly efficient, inert, water-soluble agent, and 2\% CHX gluconate at $\mathrm{pH}$ 7.0. Ferraz et al. (2001) assessed the CHX gel as an endodontic irrigant in vitro. The results indicated that the CHX gel produced a cleaner root canal surface and had an antimicrobial activity comparable with that obtained with the other solutions ( $\mathrm{NaOCl}$ and $\mathrm{CHX}$ liquid) tested. It was concluded that chlorhexidine gluconate in gel form has potential for use as an endodontic lubricant. Dametto et al. (2005) assessed in vitro the antimicrobial activity of $2 \%$ CHX gel against teeth infected with $E$. faecalis, comparing it to other endodontic irrigants (2\% CHX liquid and $5.25 \% \mathrm{NaOCl}$ ). The results showed that the antimicrobial abilities of $2 \%$ CHX gluconate, gel and liquid form, were more effective than $5.25 \% \mathrm{NaOCl}$ in suppressing $\mathrm{CFU}$ of $E$ faecalis for 7 days after the biomechanical preparation. In another study, Gomes et al. (2003) showed that 2\% CHX gel alone was more effective against $E$. faecalis than calcium hydroxide as an intracanal dressing 
in extracted bovine teeth infected with E. faecalis. It appeared that CHX in a gel form required a much longer time to kill $E$. faecalis than the corresponding concentration in a liquid (Vianna et al. 2004).

There are limited clinical studies available in the literature regarding the effectiveness of $2 \% \mathrm{CHX}$ in disinfecting root canal system. One study showed that the antibacterial activity of $2 \% \mathrm{CHX}$ gluconate solution is superior to that of $5.25 \% \mathrm{NaOCl}$ in infected root canal (Ercan et al. 2004). However, there was no statistical difference between two endodontic irrigants, probably due to the small sample numbers. Another study evaluated the addition of a $2 \% \mathrm{CHX}$ rinse to a conventional treatment protocol in the enhancement of the rate of the successful disinfection of the root canal system (Zamany et al. 2004). Cultivable bacteria were recovered in 7 out of 12 cases treated with a conventional protocol (instrumentation with $5.25 \% \mathrm{NaOCl}$ ) while only 1 out of 12 cases treated with a conventional protocol and final rinse with $2 \% \mathrm{CHX}$ solution had bacterial growth. 


\section{CHAPTER 2}

\section{PURPOSE}

Despite its promising results from in vitro studies, clinical studies addressing effectiveness of $2 \% \mathrm{CHX}$ gel have been limited. The objective of this study was to evaluate the effectiveness of $2 \% \mathrm{CHX}$ gel to eradicate endodontic infection in patients with apical periodontitis. The additional antibacterial effect of $\mathrm{Ca}(\mathrm{OH})_{2}$ mixed with $2 \% \mathrm{CHX}$ gel as a paste for an intracanal dressing was also assessed. 


\section{CHAPTER 3}

\section{MATERIALS AND METHODS}

\section{3a. In Vitro Evaluation of $2 \%$ CHX Gel Neutralizer}

An effective method of inactivating 2\% CHX solution by $3 \%$ Tween 80 and $0.3 \%$ L$\alpha$-lecithin was previously shown in the literature (Zamany and Spångberg 2002). However, whether $3 \%$ Tween 80 and $0.3 \%$ L- $\alpha$-lecithin can effectively neutralize $2 \%$ CHX gel (Endogel, Itapetininga, SP, Brazil) has not been evaluated. To address this issue, the following in vitro study was carried out based on the protocol described by Zamany and Spångberg (2002).

\section{$\underline{\text { Bacterial Cell Suspensions }}$}

E. faecalis was cultivated on blood agar medium for 24 hours. Colonies were harvested from the surface of the agar plate and suspended in a $0.43 \%$ solution of sodium chloride, centrifuged at about $400 \mathrm{~g}$ for 10 minutes, washed twice, and resuspended. They were centrifuged and finally resuspended in $0.43 \%$ solution of sodium chloride. A stock cell

suspension with a density of $2 \times 10^{4}$ viable cells per $\mathrm{mL}$ was prepared. The cell density was determined by measuring light absorbance with a spectrophotometer (Ultrospec LKB Biochrom, Rochester, NY) at a wavelength of $580 \mathrm{~nm}$ according to MacFarland's scale (Remel, Lenexa, Kan). Utility cell suspensions were prepared by diluting the stock cell 
suspension in $0.43 \%$ solution of sodium chloride. Each cell suspension was used within 30 minutes of preparation.

\section{Test Procedure}

Three percent (3\%) Tween 80 plus $0.3 \%$ L- $\alpha$-phosphatidylcholine (L- $\alpha$-lecithin) was prepared by dissolving $0.75 \mathrm{~g}$ of L- $\alpha$-lecithin (Sigma Chemical) in $3 \mathrm{~mL}$ of Tween 80 , and adjusting the final volume by adding $97 \mathrm{~mL}$ of $0.43 \%$ sterile saline solution.

$1 \mathrm{~mL}$ of $2 \% \mathrm{CHX}$ gel (Endogel, Itapetininga, SP, Brazil) was tested against $9 \mathrm{~mL}$ of $3 \%$ Tween 80 plus $0.3 \% \mathrm{~L}-\alpha$-lecithin at room temperature $\left(25^{\circ} \mathrm{C}\right)$ for $5 \mathrm{~min}$ in a sterile test tube containing glass beads (diameter, $3 \mathrm{~mm}$ ). $0.1 \mathrm{~mL}$ of bacterial cell suspension, containing $2 \times 10^{4}$ viable cells was added to this mixture. At 10 and 60 minutes, 3 glass beads and $0.1 \mathrm{~mL}$ aliquots were withdrawn and spread over the surface of two blood agar plates by means of the glass beads, which were incubated at $37^{\circ} \mathrm{C}$ for 72 hours. The numbers of colony-forming units (CFU) on the blood agar plates were recorded. The experiment was repeated and the mean CFUs from two experiments were calculated and recorded. To observe the storage life of the neutralizing agent, the same experiment was carried out weekly for a period of 3 months.

To test the effectiveness of $2 \% \mathrm{CHX}$ gel, $0.1 \mathrm{~mL}$ of bacterial cell suspension was tested against the mixture of $9 \mathrm{~mL}$ of $0.43 \%$ sterile saline and $1 \mathrm{~mL}$ of $2 \% \mathrm{CHX}$ gel, which was equilibrated for $5 \mathrm{~min}$.

To confirm that 3\% Tween 80 plus $0.3 \%$ L- $\alpha$-lecithin did not have antimicrobial effect, $0.1 \mathrm{~mL}$ of bacterial cell suspension was tested against the mixture of $9 \mathrm{~mL}$ of $0.43 \%$ sterile saline and $1 \mathrm{~mL}$ of the neutralizing agent which was equilibrated for $5 \mathrm{~min}$. 
For the positive control, $0.1 \mathrm{ml}$ of bacterial cell suspension was added to the mixture of $10 \mathrm{~mL}$ of $0.43 \%$ sterile saline.

\section{3b. Subject Recruitment and Qualification}

Approval for the project was obtained from the University of North Carolina School of Dentistry Committee on Investigation Involving Human Subjects. Patients presenting to the University of North Carolina School of Dentistry graduate endodontic clinic for evaluation and treatment of infected pulps with apical periodontitis as verified radiographically were considered for this study. The primary investigator conducted all clinical and sampling procedures. Patient selection and treatment began in January 2006 and ended in December 2006. The nature of study, complications and associated risks were fully explained to the patients or patients' guardians and consents were obtained prior to the treatment (Appendix 1). Each patient was assigned a reference number that only the primary investigator knew. References to individual treatment were by reference number to maintain confidentiality.

All teeth types were included in the study. The mesio-buccal roots of the mandibular first and second molars, the distal roots of maxillary first and second molars, the buccal roots of maxillary first premolars, and single rooted teeth were sampled and included in the study. Inclusion criteria were:

- Radiographic evidence of a periapical radiolucent lesion associated with tooth.

- Necrotic pulp as indicated by thermal or electric pulp testing.

- No history of previous endodontic treatment of the tooth

- Enough crown structure for adequate isolation 
Exclusion criteria were:

- Teeth with unfavorable conditions for rubber-dam application.

- Vital pulp tissue observed during the treatment.

- Immature teeth with open apices

\section{3c. Treatment Group Assignment}

Qualified subjects were accepted into the study in a non-random consecutive sample and treated with ProFile 0.04 taper nickel-titanium files (Dentsply/Tulsa Dental, Tulsa, Oklahoma) and 2\% CHX gel as disinfectant. Upon the completion of root canal instrumentation at the end of first appointment, all teeth were dressed with $\mathrm{Ca}(\mathrm{OH})_{2}$ mixed with 2\% CHX gel for at least 2 weeks. In this study, forty-three patients diagnosed with apical periodontitis were included as the test subjects and four patients with irreversible pulpitis as the negative control subjects.

\section{3d. Bacteria Sampling}

Each tooth was isolated with rubber dam and disinfected with $30 \%$ hydrogen peroxide until no further bubbling of the peroxide occurred. If difficulty occurred in attaining a bubble-free status, Oraseal Putty (Ultradent Products Inc., South Jordan, UT) was placed around the neck of the tooth and the process repeated. All surfaces were then coated with tincture of iodine and allowed to dry. Gross caries removal and initial access form were accomplished with sterile high speed and low speed burs. The rubber dam and surrounding tooth structure were disinfected with iodine tincture before completing the access with another sterile bur. After access was achieved, cases were randomly selected for sterility 
testing of the operating field. The tooth surface was swabbed with a 5\% sodium thiosulfate solution to inactivate the iodine tincture so that residual iodine would not influence bacteriologic sampling (Pocock 1983). To assess the efficacy of the disinfection procedure, a sterile cotton pellet was moistened in $5 \%$ sodium thiosulfate solution and used to swab the access cavity. The swab was then transferred to a vial containing $1 \mathrm{ml}$ of liquid dental transport medium (LDTM) (Anaerobe Systems, Morgan Hill, CA) and sampled for bacterial growth. Sterile saline was used to flush debris within the chamber. A description of the 3 samples (S1, S2, S3) taken in the study is found in Table 1.

\section{Initial Sample (S1)}

Bacteria samples were collected from the mesiobuccal canals of mandibular molars, distobuccal canals of maxillary molars, buccal canals of upper premolars, and single-rooted teeth. In multi-rooted teeth, sterile orifice openers (Dentsply/Tulsa Dental) were used to open the orifices of canals not used in this study, and those canal orifices were sealed with Cavit (ESPE, Norristown, PA) until all samples collected. A new sterile orifice opener (Dentsply/Tulsa Dental) was used to initiate the access into the canals of interest. Sterile saline was again used to flush any debris from the chamber. The chamber was dried with sterile cotton pellets and/or paper points before placement of Liquid Dental Transport Media (LDTM) (Anaerobic Systems, Morgan Hill, CA) into the canals of interest with a sterile tuberculin syringe. The canals were instrumented to size ISO \#15 with sterile stainless steel K-file (Kerr, Romulus, MI) to within $1 \mathrm{~mm}$ of the estimated working length. The LDTM remaining in the canal was soaked up and transferred to the LDTM vial with sterile $\mathrm{xx}$-fine paper points (Mynol, Block Drug Corp., Jersey City, NJ) placed as close to working length as

possible. This constituted the initial sample (S1). All samples were reached the laboratory within 24 h. The description of initial sampling is shown in Figure 1. 


\section{$\underline{\text { Instrumentation }}$}

Working length was established to the root terminus using an apex locator (Root ZX ${ }^{\circledR}$, J. Morita, Irvine, CA) and confirmed radiographically, $0.5-1.0 \mathrm{~mm}$ short of radiographic apex. The canals and pulp chambers were filled with $2 \% \mathrm{CHX}$ gel using 30 gauge MaxiProbe irrigation needles (Dentsply Int. Inc., York, PA) before instrumentation. Sterile ProFile 0.04 taper nickel-titanium files (Dentsply/Tulsa Dental, Tulsa, Oklahoma) were used to instrument the canals by a crown-down technique to standardized apical sizes. Rotary instrumentation was used with an Aseptico ITR Electric Torque Control Motor (Dentsply/Tulsa Dental, Tulsa, Oklahoma) rotating at $300 \mathrm{rpm}$. The mesiobuccal canals of mandibular molars, distobuccal canals of maxillary molars, and buccal canals of upper premolars were instrumented to apical size \#40.04. All single-rooted teeth were instrumented to apical size \#60.04. The apical preparation size based on the tooth type is shown in Table 2. The canals were irrigated with saline using a 30 gauge Maxi-Probe irrigation needles (Dentsply International, PA) followed by replenishing with $2 \% \mathrm{CHX}$ gel between files. After the instrumentation, the canal spaces were filled with $2 \% \mathrm{CHX}$ gel for 2 min followed by final rinse with $10 \mathrm{~mL}$ of physiological saline.

\section{Post-instrumentation Sample (S2)}

The canals were flushed with $2 \mathrm{ml}$ of $3 \%$ Tween 80 plus $0.3 \%$ L- $\alpha$-lecithin (Sigma Corp, St. Louis, MO) (Zamany and Spångberg 2002) to neutralize 2\% CHX gel. The canals were then flushed with $2 \mathrm{ml}$ sterile saline and dried with sterile paper points. Using a new set of sterile instruments, the canals were filled with LDTM and the final file sizes were placed to the working length. Files were pumped five times with minimal reaming motion. The entire canal content were absorbed with sterile paper points and transferred to the LDTM sample vial. This constituted the post-instrumentation sample (S2). All samples reached the 
laboratory within $24 \mathrm{~h}$. Once samples were collected from the canals of interest, Cavit (ESPE, Norristown, PA) was removed from the remaining canals followed by instrumentation with $2 \% \mathrm{CHX}$ gel. The description of post-instrumentation sampling is shown in Figure 2.

\section{Intracanal medicament}

The canals were again filled with $2 \% \mathrm{CHX}$ gel for $2 \mathrm{~min}$, then saline and dried with paper points. A mixture of $\mathrm{Ca}(\mathrm{OH})_{2}$ and $2 \% \mathrm{CHX}$ gel was placed into all canals with a Lentulo spiral filler (Caulk, Milford, Delaware) and the access cavity was sealed with IRM (Dentsply Int. Inc., York, PA). The intracanal medication of the $\mathrm{Ca}(\mathrm{OH})_{2}$ mixed with $2 \%$ CHX gel was placed for a minimum of two weeks.

\section{Post-Dressing (S3)}

At the second appointment, under rubber dam isolation the tooth was accessed with the strict aseptic protocol described above. Intracanal medicament was passively removed with a K-file and sterile saline irrigation. The remaining canals were again sealed with Cavit (ESPE, Norristown, PA) till the sample collected from the canal of interest. Neutralization of the $\mathrm{Ca}(\mathrm{OH})_{2} / 2 \% \mathrm{CHX}$ gel dressing was accomplished with $2 \mathrm{ml} 0.5 \%$ citric acid followed by $2 \mathrm{ml} 3 \%$ Tween $80 / 0.3 \%$ L- $\alpha$-lecithin introduced into each canal with a sterile tuberculin syringe with 30 gauge Maxi-Probe irrigation needle (Dentsply Int. Inc., York, PA). The canals were irrigated again with sterile saline and dried. As described above, LDTM was introduced and collected, constituting the final sample (S3). The description of post-dressing sampling is shown in Figure 3.

The laboratory procedures were performed at the University of North Carolina Dental Microbiology Laboratory (a CLIA certified laboratory). The vials with the paper point samples were agitated with a vortex with a setting of four before aliquot disbursement. 
Sample dilutions of 10 and 100-fold were prepared under anaerobic conditions using sterile glassware. Petri dishes with anaerobic sheep blood agar supplemented with heme and vitamin $\mathrm{K}$ were quantitatively inoculated by spiral plating of undiluted sample, as well as each of the two dilutions. A model D spiral plater (Microbiology International) delivered $49 \mu \mathrm{l}$ of sample to each agar plate. The Model D spiral plater delivered a $2.3 \log$ dilution of the sample across each plate. Plates were incubated at $37^{\circ} \mathrm{C}$ for 7 days in an anaerobic chamber containing $10 \%$ hydrogen, $85 \%$ nitrogen, and $5 \% \mathrm{CO}_{2}$. The bacteria growth was measured by direct counting of colonies and grid specific calculations. The spiral plater deposited a known volume of the sample to areas of the plate or grid. Once the colonies

were counted in each grid, a dilution factor (determined by manufacturer) was used to translate the grid calculations to the original bacterial count in the sample.

\section{3e. Data Analysis}

The number of positive culture was also recorded at S1, S2, and S3. Fisher's exact tests were used to detect the differences in the number of positive culture between S1 and S2, S1 and S3, or S2 and S3. The level of significance was set at 0.05 for all analyses. 


\section{CHAPTER 4}

\section{RESULTS}

\section{4a. In Vitro Evaluation of $2 \%$ CHX Gel Neutralizer}

$3 \%$ Tween 80 plus $0.3 \%$ L- $\alpha$-lecithin was found to be an effective inactivating agent, ensuring full recovery of $E$. faecalis in the presence of $2 \% \mathrm{CHX}$ gel. The duration of contact time (10 $\mathrm{min}$ or $60 \mathrm{~min}$ ) had no effect on the recovery of the organisms when $3 \%$ Tween 80/0.3\% L- $\alpha$-lecithin tested with and without $2 \% \mathrm{CHX}$ gel. No test organisms were recovered when E. faecalis tested against 2\% CHX gel (negative control). $3 \%$ Tween 80/0.3\% L- $\alpha$-lecithin yielded full recovery of E. faecalis (positive control).

The same experimented repeated weekly for 12 weeks with the same neutralizing agent prepared initially. At the $12^{\text {th }}$ week, full recovery of E. faecalis was still obtained when $3 \%$ Tween 80 plus $0.3 \%$ L- $\alpha$-lecithin mixed with $2 \%$ CHX gel.

\section{4b. In Vivo Evaluation of the Clinical Efficacy of $2 \%$ CHX Gel}

Forty-three test subjects and four negative control subjects were included in the study. Teeth were instrumented to standardized sizes, \#40 or \#60, depending on the tooth type (Table 2). The bacterial counts (CFU/ml) for each sample are listed in Table 3. The sample distribution based on the bacterial counts at $\mathrm{S} 1, \mathrm{~S} 2$, and $\mathrm{S} 3$ are described in Figure 4-6. Percentage of root canals with negative culture in the S2 and S3 samples are summarized in 
Table 4 and Figure 7. All four negative control subjects showed no bacteria growth at S1, S2, and S3.

Bacteria were initially present in 39 of the 43 test teeth. Four test teeth with no initial bacterial growth were excluded from analysis. Of the teeth with positive culture at S1, 18 teeth were prepared to \#60 and 21 teeth were prepared to \#40.

Of the teeth that were culture positive at S1, 35 out of $39(89.7 \%)$ were negative for culture at S2. For the size \#40 and \#60 groups, 19/21 (90.5\%) and 16/18 (88.9\%) had negative culture, respectively. There was no statistical difference in the numbers of negative culture between these two groups at $\mathrm{S} 2(\mathrm{p}=0.871)$.

The average number of days of calcium hydroxide therapy was 19 days with a range of 14 to 29 days. Three samples in S3 were lost during culturing. Of the remaining samples, 33/36 (91.7\%) were free of bacteria at S3. For the size \#40 and \#60 groups, 18/19 (94.7\%) and 15/17 (88.2\%) had negative culture, respectively. There was no statistical difference in the numbers of negative culture between these two groups at $\mathrm{S} 3(\mathrm{p}=0.481)$. All four samples that were culture positive at $S 2$ were free of bacteria at $S 3$, but three samples that were culture negative at $\mathrm{S} 2$ had recoverable $\mathrm{CFU}$ at $\mathrm{S} 3$.

The Fisher's Exact test showed a significant difference in the numbers of positive culture between S1 and S2 $(\mathrm{p}<0.001)$ and between S1 and S3 $(\mathrm{p}<0.001)$. There was no statistical difference in the numbers of negative culture between S2 and S3 ( $p=0.692)$. 


\section{CHAPTER 5}

\section{DISCUSSION}

Effectiveness of 2\% CHX solution or gel as antimicrobial agent was well investigated in vitro. It appeared that $\mathrm{CHX}$ and $\mathrm{NaOCl}$ have similar antimicrobial activity against the common organisms isolated from the root canal system (Estrela et al. 2003, Vianna et al. 2004). There are several advantages for the clinical use of CHX as root canal disinfectant over $\mathrm{NaOCl}$, including low toxicity (Filho et al. 2002), substantivity (Rosenthal et al. 2004), and lack of bleaching. Despite its promising results from in vitro studies, there are not enough clinical studies published on literature so far. In this study, we evaluated the bacteria reduction activity of $2 \% \mathrm{CHX}$ gel as root canal disinfectant in patients with apical periodontitis.

An effective method of inactivating $2 \% \mathrm{CHX}$ solution was shown previously by Zamany and Spångberg (2002). The authors used L- $\alpha$-lecithin, Tween 80, and sodium thiosulfate in different proportions to prepare 6 potential inactivating solutions. Inactivating agents and 2\% CHX solution were tested against E. faecalis on blood agar plate. They showed that the combination of $3 \%$ Tween- 80 and $0.3 \%$ L- $\alpha$-lecithin was the most effective inactivating agent. However whether 3\% Tween 80 plus $0.3 \%$ L- $\alpha$-lecithin can effectively neutralize 2\% CHX gel (Endogel, Itapetininga, SP, Brazil) had not been evaluated yet. To address this, an in vitro experiment was carried out based on the protocol described by 
Zamany and Spångberg (2002). In addition, we repeated the same experiment weekly for 12 weeks using the same neutralizing agent prepared. Our data confirmed that 3\% Tween 80 plus $0.3 \% \mathrm{~L}-\alpha$-lecithin is a good neutralizing agent for $2 \% \mathrm{CHX}$ gel and it is effective at least for 12 weeks.

Although numerous in vitro studies evaluated the antimicrobial properties of $2 \%$ CHX gel, there is only one clinical study available in the literature. Vianna et al. (2006) evaluated the microbial reduction after chemo-mechanical preparation of human root canals containing necrotic pulp tissue. Thirty-two single rooted teeth with necrotic pulp and apical periodontitis (from 32 patients) were selected for this study. One group $(n=16)$ was irrigated with $2.5 \% \mathrm{NaOCl}$ during the root canal instrumentation while the other group $(\mathrm{n}=16)$ was irrigated with $2 \% \mathrm{CHX}$ gel. Bacterial load was assessed by the use of real-time quantitativepolymerase chain reaction (RTQ-PCR) and the traditional culturing techniques. RTQ-PCR showed that the bacterial reduction was greater in the NaOCl-group than in the CHX-group. According to culture technique $75 \%$ of cases were free of bacteria after chemo-mechanical preparation in the $\mathrm{NaOCl}$-group, while $50 \%$ of cases were bacteria free in the $\mathrm{CHX}$-group. The authors concluded that $2.5 \% \mathrm{NaOCl}$ was a more effective root canal irrigant than $2 \%$ CHX gel.

In contrast, our results showed that $2 \% \mathrm{CHX}$ gel was an effective root canal disinfectant and close to $90 \%$ of cases were void of recoverable bacteria after the chemomechanical preparation. This disparity is probably due to the differences in clinical procedures of the two studies. In our study, all single rooted teeth were prepared to a standardized size of \#60/.04 using rotary NiTi instruments while Vianna et al. (2006) prepared to the apical size of \#35-45 using K-files followed by step back instrumentation. 
Previous studies have shown that uniform reduction of bacteria occurred with progressive filing (Dalton et al. 1999, Siqueira et al. 1999, Shuping et al. 2000, Card et al. 2000). Higher load of bacterial reduction is expected for a larger apical preparation. Thus, favorable results observed in our study could be due to the combination of larger apical preparation and chemical disinfection property of $2 \% \mathrm{CHX}$ gel.

In addition, the irrigation methods used for irrigation were different between these studies. Vianna et al. (2006) stated that the use of each instrument was followed by irrigation with a syringe containing $1 \mathrm{ml}$ of $2 \% \mathrm{CHX}$ gel and immediately after with $4 \mathrm{ml}$ of saline. On the other hand, we filled the root canal with $2 \% \mathrm{CHX}$ gel and instrumented with a rotary NiTi file followed by rinse with physiologic saline. This procedure was repeated for each file until the final preparation. In addition, the root canals were soaked with $2 \% \mathrm{CHX}$ gel for $2 \mathrm{~min}$ after the instrumentation followed by copious rinsing with physiologic saline. The advantages of our approach are to allow $2 \% \mathrm{CHX}$ gel to have sufficient contact time and physical contact with the root canal walls. Unlike $2 \% \mathrm{CHX}$ solution, the gel form requires a longer contact time for effective disinfection. In vitro studies showed $2 \% \mathrm{CHX}$ solution and $5.25 \% \mathrm{NaOCl}$ had similar antimicrobial activities and required about the same amount of time to eliminate microorganisms (Estrela et al. 2003, Vianna et al. 2004). However, 2\% $\mathrm{CHX}$ gel requires much longer time to eliminate microorganisms compared to $2 \% \mathrm{CHX}$ solution and 5.25\% NaOCl (Vianna et al. 2004).

In addition to the contact time, adequate delivery of $2 \% \mathrm{CHX}$ gel to the root canal system is an important factor, particularly in curved roots. Unlike the solution, the gel form does not have a good flowing property. It requires additional attention to deliver the gel to the root canal system. This was accomplished in our study by several ways. First, root canal 
preparations were performed with rotary NiTi instruments in the canals filled with $2 \% \mathrm{CHX}$ gel. By this way, the gel was physically delivered throughout the root canal system as the rotary files contacting the walls. Secondly, larger apical preparation would allow adequate lubrication of the apical third (Shuping et al. 2000, Ram et al. 1977, Chow et al. 1983, Siqueira et al. 1999). Third, we used 30 gauge Maxi-Probe irrigation needle (Dentsply Int. Inc., York, PA) to deliver 2\% CHX gel. Because of its small diameter, the needle was able to be placed close to the working length and allowed the proximity to the anatomical foramen.

On average, $40 \%$ - $60 \%$ of root canals have no cultivable bacteria after chemomechanical root canal preparation with $\mathrm{NaOCl}$ solution (Dalton et al. 1999, Shuping et al. 2001, Card et al. 2002, McGurkin-Smith et al. 2005, Kvist et al. 2004). Shuping et al. (2000) evaluated the extent of bacterial reduction with NiTi rotary instrumentation and $1.5 \%$ $\mathrm{NaOCl}$ irrigation in 42 patients with apical periodontitis. Bacterial samples were taken before and after the instrumentation, and they were cultured anaerobically for 7 days. The authors found $62 \%$ of canals were rendered bacteria-free after instrumentation with $1.5 \%$ $\mathrm{NaOCl}$. Using similar clinical protocol, McGurkin-Smith et al. (2005) obtained 40\% of canals sampled bacteria free after instrumentation and a strict irrigation protocol using $5.25 \%$ $\mathrm{NaOCl}$ and EDTA. It seems that increasing the $\mathrm{NaOCl}$ concentration from $1.5 \%$ to $5.25 \%$ did not increase the percentage of canals sampled bacteria free. On the other hand, our results showed that $89.7 \%$ of canals prepared with $2 \% \mathrm{CHX}$ gel cultured bacteria free. There was no difference between the canals prepared to \#40.04 and \#60.04 in the percentage of bacteria reduction (Figure 7). It appears that $2 \% \mathrm{CHX}$ gel is a more effective disinfectant than 1.5-5.25\% $\mathrm{NaOCl}$ when it is used as in this study (Figure 8). Nonetheless, direct comparison among these studies is not possible even though they were done from the same 
institution following similar clinical procedures and treatment philosophy. Currently, we are investigating the clinical efficacy of $2 \% \mathrm{CHX}$ gel vs. $5.25 \% \mathrm{NaOCl}$ as well.

To obtain a more predictable microbial control, placement of intracanal medicament of $\mathrm{Ca}(\mathrm{OH})_{2}$ is often recommended (Byström et al. 1985, Sjögren et al. 1991, Shuping et al. 2002). Studies consistently demonstrated that $\mathrm{Ca}(\mathrm{OH})_{2}$ can help to further eliminate surviving bacteria in the root canals (Sjögren et al. 1991, Ørstavik et al. 1991, Shuping et al. 2002). However, a minimum of two-visit root canal treatment is required when using $\mathrm{Ca}(\mathrm{OH})_{2}$ intracanal dressing because it is ineffective when used as short-term medicament (Sjögren et al. 1991). Although $\mathrm{Ca}(\mathrm{OH})_{2}$ is a good antimicrobial agent, it is ineffective against some of the microorganisms such as E. faecalis (Sjögren et al. 1991, Haapasalo and Ørstavik 1987, Heling et al. 1992), which is found in the case of persistent root canal infection.

To improve the antimicrobial efficacy of $\mathrm{Ca}(\mathrm{OH})_{2}$ against E. faecalis, the combination of $\mathrm{Ca}(\mathrm{OH})_{2}$ and $2 \% \mathrm{CHX}$ gel was used in this study. Gomes et al. (2006) demonstrated that $\mathrm{Ca}(\mathrm{OH})_{2}$ mixed with $2 \% \mathrm{CHX}$ gel had better antimicrobial activity than $\mathrm{Ca}(\mathrm{OH})_{2}$ manipulated with sterile water in an in vitro study. In addition, Siren et al. (2004) showed $\mathrm{Ca}(\mathrm{OH})_{2}$ was unable to kill E. faecalis in the dentine, $\mathrm{Ca}(\mathrm{OH})_{2}$ combined with $\mathrm{CHX}$ effectively disinfected the dentine. Other studies also support that mixture of $\mathrm{Ca}(\mathrm{OH})_{2}$ and CHX solution is more effective in eliminate E. faecalis than $\mathrm{Ca}(\mathrm{OH})_{2}$ alone (Ercan et al. 2006, Zerrella et al. 2005, Podbielski et al. 2003, Evan et al. 2003).

In our study, placement of $\mathrm{Ca}(\mathrm{OH})_{2} / 2 \% \mathrm{CHX}$ gel intracanal dressing for at least 2 weeks rendered $91.7 \%$ of canals bacteria free in teeth with apical periodontitis. This value is consistent with the previous reports (Figure 8). Shuping et al. (2000) had 92.5\% of canals bacteria free when placing for $\mathrm{Ca}(\mathrm{OH})_{2}$ alone at least 1 week. McGurkin-Smith et al. (2005) 
had $86 \%$ of canals bacteria free after 2 weeks of $\mathrm{Ca}(\mathrm{OH})_{2}$ alone. Interestingly, unlike those studies, we did not find significant improvement of the root canal disinfection with additional intracanal dressing (Figure 8). This does not imply that $\mathrm{Ca}(\mathrm{OH})_{2} / 2 \%$ CHX gel intracanal dressing is ineffective. Rather it demonstrated that $2 \%$ CHX gel is an effective root canal disinfectant.

The purpose of two visit root canal treatment using intracanal dressing (such as $\mathrm{Ca}(\mathrm{OH})_{2}$ ) is to predictably control the root canal infection (Trope et al. 1991). This is important because the negative culture prior to the root canal filling is related to long term root canal treatment success (Sjögren et al. 1997, Byström et al.1987). However, some studies questioned the effectiveness of calcium hydroxide to disinfect the canals, and reported a residual flora in the canals after more than one week of the intracanal dressing. (Reit et al.1999, Peters et al. 2002, Kvist et al. 2004, Waltimo et al. 2005). In some cases, residual bacteria in the canal grew in number even in the presence of calcium hydroxide (Peters et al. 2002, Waltimo et al. 2005). We had a similar finding in our study. Three samples showed no bacteria growth after root canal preparation with $2 \% \mathrm{CHX}$ gel but the bacteria were detected after two weeks of $\mathrm{Ca}(\mathrm{OH})_{2} / 2 \%$ CHX gel intracanal dressing. Ideally, one-visit root canal treatment is desirable if predictable root canal disinfection can be achieved. Our results showed that $2 \% \mathrm{CHX}$ gel is an effective root canal disinfectant and additional intracanal dressing did not significantly improve the disinfection. Hence, we can speculate that one-visit root canal treatment with $2 \%$ CHX gel can be performed without compromising its long term success. Nonetheless, further investigations are required to support this hypothesis. 


\section{CHAPTER 6}

\section{CONCLUSION}

There was a statistically significant difference in bacterial reduction between the initial sample (S1) and the post-instrumentation sample (S2) when 2\% CHX gel used as root canal disinfectant. Instrumentation with $2 \% \mathrm{CHX}$ gel was effective in bacterial reduction and resulted in $89.7 \%$ of canals becoming free of bacteria. The addition of the mixture of $\mathrm{Ca}(\mathrm{OH})_{2}$ and $2 \%$ CHX gel paste as an intracanal medicament for at least two weeks produced $91.7 \%$ of canals void of bacteria. However, there is no statistically significant decrease in the numbers of canal free of bacteria between the post-instrumentation sample (S2) and post intracanal medicament sample (S3). 


\section{CHAPTER 7}

\section{SUMMARY}

In this study, we assessed the ability of Ni-Ti rotary instrumentation with $2 \% \mathrm{CHX}$ gel in the reduction of intracanal bacteria. In addition, the effect of at least 2 weeks of $\mathrm{Ca}(\mathrm{OH})_{2} / 2 \% \mathrm{CHX}$ gel dressing on intracanal bacteria was also evaluated.

Forty-three patients with clinical and radiographic signs of apical periodontitis were accepted into the study. All patients received instrumentation with 0.04 NiTi rotary instruments and $2 \% \mathrm{CHX}$ gel, followed by at least 2 weeks of $\mathrm{Ca}(\mathrm{OH})_{2} / 2 \% \mathrm{CHX}$ gel therapy. Four additional vital teeth with a diagnosis of irreversible pulpitis and a normal periapex were treated in the same manner as the study teeth and served as negative controls. The mesiobuccal canals of mandibular molars, distobuccal canals of maxillary molars, and buccal canals of upper premolars were instrumented to apical size \#40.04. All single-rooted teeth were instrumented to apical size \#60.04. Samples were collected from those canals.

All teeth were sampled prior to (S1), after instrumentation (S2), and after 2 weeks of $\mathrm{Ca}(\mathrm{OH})_{2} / 2 \% \mathrm{CHX}$ gel dressing (S3). The teeth were sampled using the pumping maximum removal method with Liquid Dental Transport Media (LDTM) as the sampling media. All samples were diluted, plated on sheep agar, and incubated anaerobically at $37^{\circ} \mathrm{C}$ for seven days. The plates were then observed, the CFUs counted, and positive culture counted. 
Fisher's exact tests were used to detect the differences in the number of positive culture between $\mathrm{S} 1$ and $\mathrm{S} 2, \mathrm{~S} 1$ and $\mathrm{S} 3$, or $\mathrm{S} 2$ and $\mathrm{S} 3$. The level of significance was set at 0.05 for all analyses.

The relationship between bacteria and apical periodontitis was shown from the initial samples of the study subjects. Four samples showed no bacteria growth at S1. Of the samples with positive growth $(\mathrm{n}=39), 10.3 \%$ (4/39) sampled bacteria at S2. At S3, three samples were lost during culture and $8.3 \%$ (3/36) of the remaining samples cultured positively. All the cases cultured positively at S2 showed no growth at S3. However, three samples cultured negatively at S2 showed bacteria growth at S3. The Fisher's exact test showed a significant difference in the percentage of positive culture between S1 and S2 $(\mathrm{p}<0.0001)$ and between $\mathrm{S} 1$ and S3 $(\mathrm{p}<0.0001)$. No significant difference was found between $\mathrm{S} 2$ and $\mathrm{S} 3(\mathrm{p}=0.692)$.

These results suggest that $2 \% \mathrm{CHX}$ gel is an effective root canal disinfectant and can be used alternative to $\mathrm{NaOCl}$ solution. 


\section{Appendix I}

\section{Consent Form Example}

\section{University of North Carolina-Chapel Hill \\ Consent to Participate in a Research Study \\ Adult Subjects \\ Biomedical Form}

\section{IRB Study \#__ 05-DENT-769}

Consent Form Version Date:__ 1-18-2006

Title of Study: Efficacy of 2\% Chlorhexidine Gel in Disinfecting the Root-Canal System: a clinical study

Principal Investigator: Ching Shan Wang, DDS

UNC-Chapel Hill Department: Endodontics

UNC-Chapel Hill Phone number: (919)966-2709

Email Address: $\quad$ wangc@dentistry.unc.edu

Faculty Advisor: $\quad$ Fabricio B. Teixeira, DDS, MS, Ph.D

Martin Trope, DDS, MS

Rolald Arnold, DDS, Ph.D.

Funding Source: AAE foundation

Study Contact telephone number: (919)966-2709

Study Contact email: $\quad$ wangc@dentistry.unc.edu

\section{What are some general things you should know about research studies?}

You are being asked to take part in a research study. To join the study is voluntary.

You may refuse to join, or you may withdraw your consent to be in the study, for any reason.

Research studies are designed to obtain new knowledge that may help other people in the future. You may not receive any direct benefit from being in the research study. There also may be risks to being in research studies.

Deciding not to be in the study or leaving the study before it is done will not affect your relationship with the researcher, your health care provider, or the University of North Carolina-Chapel Hill. If you are a patient with an illness, you do not have to be in the research study in order to receive health care. 
Details about this study are discussed below. It is important that you understand this information so that you can make an informed choice about being in this research study. You will be given a copy of this consent form. You should ask the researchers named above, or staff members who may assist them, any questions you have about this study at any time.

\section{What is the purpose of this study?}

The purpose of this study is to test how effective $2 \%$ chlorhexidine gel can disinfect a root canal. To reduce the bacteria in a root canal is important, because it can significantly affect the long term outcome of root canal treatment. Chlorhexidine, an antiseptic belonging to family of biguanides, is used extensively in the medical and surgical environment. In dentistry, it is often used as mouth rinse solution.

Recently, $2 \%$ chlorhexidine gel was introduced as root canal disinfectant. Research studies not using patients have shown that $2 \%$ chlorhexidine gel is a very effective antimicrobial agent for disinfecting root canal, especially it can kill certain bacteria resisting to the conventional disinfectant. In addition, chlorhexidine does cause obvious toxic effects when used intraorally. Unlike some disinfectant, it does not have bad taste and stain cloth easily. Therefore, these properties make $2 \%$ chlorhexidine gel a suitable alternative to the conventional root canal disinfectant.

In this study, we want to evaluate the efficacy of $2 \%$ chlorhexidine gel clinically.

You are being asked to be in the study because one of your teeth has been diagnosed as necrotic pulp with apical periodontitis, indicating the need for a root canal treatment.

\section{Are there any reasons you should not be in this study?}

Pregnant women, decisionally impaired patients and patients younger than 14 years old will be excluded from the study. Medically compromised patients with conditions that are contraindicated to the dental treatment will also be excluded from the study. These include severe hypertension, uncontrollable diabetes, recent history of stroke, etc

\section{How many people will take part in this study?}

If you decide to be in this study, you will be one of approximately 40 people in this research study.

\section{How long will your part in this study last?}

You are not expected to spend any more time than 2 regular visits for your root canal treatment.

\section{What will happen if you take part in the study?}

You will have a routine root canal treatment (RCT) that follows the UNC endodontic protocol. The exception is that you might be treated with either sodium hypochlorite or $2 \%$ chlorhexidine gel as the disinfectant during the treatment. Sodium hypochlorite is most commonly used disinfectant in RCT and this solution will be used as control in this study. You will be randomly assigned to be treated with either $2 \%$ chlorhexidine gel or sodium hypochlorite. 
During the treatment, we will take bacterial samples from the root canals of your treating tooth. Total of 3 samples at 3 different time period will be taken: 1) before cleaning root canal 2) after cleaning root canal, and 3) right before root canal filling. Bacterial samples will be sent to a microbiologic lab as soon as possible for analysis. The number of bacterial count will be analyzed to examine the effectiveness of $2 \%$ chlorohexidine gel in disinfecting root canals compared to that of sodium hypochlorite.

\section{What are the possible benefits from being in this study?}

Research is designed to benefit society by gaining new knowledge.

A potential benefit to you from being in this study is that you might have better healing process after the treatment when using $2 \%$ chlorhexidine gel as compared to that of sodium hypochlorite.

In addition, you might have less unpleasant experience from foul taste and toxic effects when using $2 \%$ chlorhexidine gel as the disinfectant. Although there are possible benefits from being in this study, this cannot be guaranteed.

\section{What are the possible risks or discomforts involved with being in this study?}

It is expected that the procedures incur minimal risk. You should be aware that the treatment in this study has the same risks and possible complications as all root canal procedures, including modest pain following treatment and failure for the tooth to completely heal despite treatment. Anytime a root canal treatment is undertaken, modest pain may be anticipated. You will receive a prescription for medication or reduce discomfort if needed, though this is usually unnecessary.

Chlorhexidine is a relatively nontoxic material. Research studies have shown that $2 \%$ chlorhexidine solution when used as a periodontal irrigant did not cause obvious toxic effects on gingival tissue, suggesting its safety for intraoral use. In very rare occasion, chlorhexidine can cause acute allergic reaction when applied to skin or mucosa. However, there has been no report of allergic reaction to chlorhexidine when used as the root canal disinfectant.

In addition, there may be uncommon or previously unknown risks that might occur. You should report any problems to the researchers.

What are the risks to a pregnancy or to a nursing child?

Pregnant women will be excluded from this study. We do not know the effect of the study drug on nursing children.

If you choose not to be in the study, what other treatment options do you have?

You do not have to be in this research study in order to receive treatment. The other procedures or treatments that are available include routine root canal treatment.

What if we learn about new findings or information during the study? 
You will be given any new information gained during the course of the study that might affect your willingness to continue your participation.

\section{How will your privacy be protected?}

Only the treating dentist will know about your identity throughout the study. Specific ID numbers will be given to patients and bacterial samples. Only ID numbers will be used to communicate with the laboratory. At the end of data collection, the patient list from this study will be destroyed by paper shredder.

No subjects will be identified in any report or publication about this study. Although every effort will be made to keep research records private, there may be times when federal or state law requires the disclosure of such records, including personal information. This is very unlikely, but if disclosure is ever required, UNC-Chapel Hill will take steps allowable by law to protect the privacy of personal information. In some cases, your information in this research study could be reviewed by representatives of the University, research sponsors, or government agencies for purposes such as quality control or safety.

A copy of this consent form will go in to your medical record. This will allow the doctors caring for you to know what study medications or tests you may be receiving as a part of the study and know how to take care of you if you have other health problems or needs during the study.

\section{What will happen if you are injured by this research?}

All research involves a chance that something bad might happen to you. This may include the risk of personal injury. In spite of all safety measures, you might develop a reaction or injury from being in this study. If such problems occur, the researchers will help you get medical care, but any costs for the medical care will be billed to you and/or your insurance company. The University of North Carolina at Chapel Hill has not set aside funds to pay you for any such reactions or injuries, or for the related medical care. However, by signing this form, you do not give up any of your legal rights.

\section{What if you want to stop before your part in the study is complete?}

You can withdraw from this study at any time, without penalty. The investigators also have the right to stop your participation at any time. This could be because you have had an unexpected reaction, or have failed to follow instructions, or because the entire study has been stopped.

\section{Will you receive anything for being in this study?}

You will not receive anything for taking part in this study.

\section{Will it cost you anything to be in this study?}

It will not cost you anything in addition to what you will be billed for your routine root canal treatment to be in this study. All tests, visits or procedures other than what is done for this study will be related to dental care that is part of the usual care for your condition and would be suggested even if you decided not to be in the research study. 


\section{What if you are a UNC student?}

You may choose not to be in the study or to stop being in the study before it is over at any time. This will not affect your class standing or grades at UNC-Chapel Hill. You will not be offered or receive any special consideration if you take part in this research.

\section{What if you are a UNC employee?}

Taking part in this research is not a part of your University duties, and refusing will not affect your job. You will not be offered or receive any special job-related consideration if you take part in this research.

\section{Who is sponsoring this study?}

The study is carried out by the Department of Endodontics, UNC School of Dentistry. Currently it is not sponsored by any organization. Investigators have no financial affiliation with the products used in this study.

\section{What if you have questions about this study?}

You have the right to ask, and have answered, any questions you may have about this research. If you have questions, or if a research-related injury occurs, you should contact the researchers listed on the first page of this form.

\section{What if you have questions about your rights as a research subject?}

All research on human volunteers is reviewed by a committee that works to protect your rights and welfare. If you have questions or concerns about your rights as a research subject you may contact, anonymously if you wish, the Institutional Review Board at 919-966-3113 or by email to IRB_subjects@unc.edu.

\section{Subject's Agreement:}

I have read the information provided above. I have asked all the questions I have at this time. I voluntarily agree to participate in this research study.

Signature of Research Subject

Printed Name of Research Subject

Signature of Person Obtaining Consent

Printed Name of Person Obtaining Consent

\section{Date}

Date 


\section{Table 1. Description of samples}

S1: Initial, pre-instrumentation sample

S2: post-instrumentation sample

S3: post-dressing sample

Table 2. Apical preparation size corresponding to canal and tooth type.

\begin{tabular}{llcc} 
Tooth type & Canal & Apical sizes & Taper \\
\hline Incisors & central & $\# 60$ & .04 \\
Single rooted premolars & central & $\# 60$ & .04 \\
Maxillary premolar & buccal & $\# 40$ & .04 \\
Maxillary molar & disto-buccal & $\# 40$ & .04 \\
Mandibular molar & mesio-buccal & $\# 40$ & .04
\end{tabular}


Table 3. Bacterial counts (CFU/ml) for each sample

\begin{tabular}{|c|c|c|c|c|c|}
\hline Sample\# & Tooth\# & Apical Size & S1 & S2 & S3 \\
\hline 1 & 13 & 60 & $>10^{9}$ & 0 & 0 \\
\hline 2 & 7 & 60 & $9.63 \times 10^{5}$ & 0 & $* *$ \\
\hline 3 & 8 & 60 & $2.70 \times 10^{6}$ & $4.87 \times 10^{2}$ & 0 \\
\hline 4 & 31 & 40 & $6.09 \times 10^{2}$ & 0 & 0 \\
\hline 5 & 7 & 60 & $7.50 \times 10^{4}$ & 0 & 0 \\
\hline 6 & 31 & 40 & $5.50 \times 10^{3}$ & 0 & 0 \\
\hline 7 & 19 & 40 & $>10^{9}$ & $2.84 \times 10^{3}$ & 0 \\
\hline 8 & 8 & 60 & $1.74 \times 10^{5}$ & 0 & 0 \\
\hline 9 & 9 & 60 & $1.33 \times 10^{5}$ & 0 & 0 \\
\hline 10 & 23 & 60 & $1.81 \times 10^{5}$ & 0 & $1.01 \times 10^{2}$ \\
\hline 11 & 30 & 40 & $2.00 \times 10^{5}$ & 0 & 0 \\
\hline 12 & 4 & 60 & $0^{*}$ & $0^{*}$ & $0 *$ \\
\hline 13 & 19 & 40 & $1.71 \times 10^{5}$ & 0 & 0 \\
\hline 14 & 10 & 60 & $0 *$ & $0 *$ & $0 *$ \\
\hline 15 & 14 & 40 & $0^{*}$ & $0^{*}$ & $4.80 \times 10^{4} *$ \\
\hline 16 & 30 & 40 & $6.90 \times 10^{5}$ & 0 & 0 \\
\hline 17 & 28 & 60 & $6.40 \times 10^{2}$ & 0 & 0 \\
\hline 18 & 19 & 40 & $5.80 \times 10^{5}$ & 0 & 0 \\
\hline 19 & 19 & 40 & $2.40 \times 10^{7}$ & $1.40 \times 10^{4}$ & 0 \\
\hline 20 & 4 & 60 & $4.60 \times 10^{4}$ & 0 & 0 \\
\hline 21 & 13 & 60 & $1.40 \times 10^{7}$ & 0 & $8.90 \times 10^{4}$ \\
\hline 22 & 9 & 60 & $2.10 \times 10^{7}$ & 0 & 0 \\
\hline 23 & 5 & 40 & $1.10 \times 10^{7}$ & 0 & 0 \\
\hline 24 & 29 & 60 & $0^{*}$ & $0 *$ & $0 *$ \\
\hline 25 & 30 & 40 & $>10^{9}$ & 0 & 0 \\
\hline 26 & 15 & 40 & $>10^{9}$ & 0 & $3.20 \times 10^{2}$ \\
\hline 27 & 14 & 40 & $2.50 \times 10^{5}$ & 0 & $* *$ \\
\hline 28 & 19 & 40 & $5.50 \times 10^{5}$ & 0 & $* *$ \\
\hline 29 & 7 & 60 & $3.10 \times 10^{5}$ & $1.30 \times 10^{3}$ & 0 \\
\hline 30 & 3 & 40 & $2.50 \times 10^{5}$ & 0 & 0 \\
\hline 31 & 20 & 60 & $1.20 \times 10^{4}$ & 0 & 0 \\
\hline 32 & 29 & 60 & $1.40 \times 10^{5}$ & 0 & 0 \\
\hline 33 & 3 & 40 & $4.00 \times 10^{3}$ & 0 & 0 \\
\hline 34 & 3 & 40 & $2.30 \times 10^{4}$ & 0 & 0 \\
\hline 35 & 3 & 40 & $8.13 \times 10^{2}$ & 0 & 0 \\
\hline 36 & 9 & 60 & $6.00 \times 10^{5}$ & 0 & 0 \\
\hline 37 & 23 & 60 & $1.00 \times 10^{3}$ & 0 & 0 \\
\hline 38 & 18 & 40 & $1.40 \times 10^{5}$ & 0 & 0 \\
\hline 39 & 29 & 60 & $>10^{9}$ & 0 & 0 \\
\hline 40 & 19 & 40 & $4.20 \times 10^{5}$ & 0 & 0 \\
\hline 41 & 29 & 60 & $1.70 \times 10^{5}$ & 0 & 0 \\
\hline 42 & 18 & 40 & $2.40 \times 10^{4}$ & 0 & 0 \\
\hline 43 & 31 & 40 & $8.10 \times 10^{4}$ & 0 & 0 \\
\hline
\end{tabular}

*Initial samples with no bacterial growth, excluded from analysis

**samples lost during culturing

$>10^{9}$ represents the samples that were too numerous to count

0 represents samples below the limit of detection $\left(<10^{2}\right)$ 
Table 4. Percentage of samples with negative culture

\begin{tabular}{|c|c|c|c|}
\hline Groups & Sample Size & S2 & S3 \\
\hline Size \#60 & 18 & $16 / 18(88.9 \%)$ & $15 / 17 \quad(88.2 \%)$ \\
\hline Size \#40 & 21 & $19 / 21(90.5 \%)$ & $18 / 19(94.7 \%)$ \\
\hline Total & 39 & $35 / 39 \quad(89.7 \%)$ & $33 / 36 \quad(91.7 \%)$ \\
\hline
\end{tabular}


Figure 1: Initial, Pre-Instrumentation Sample (S1)
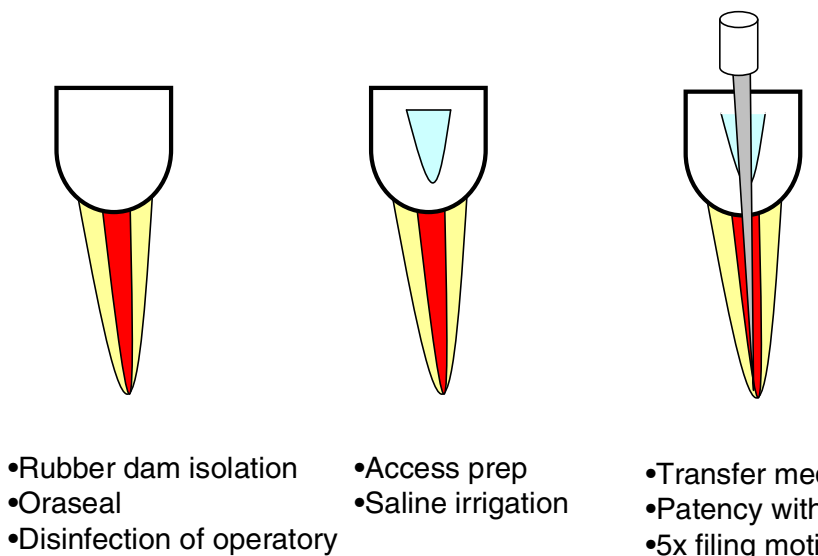

- Transfer medium

-Patency with \#15 file

-Disinfection of operatory

field

$\cdot 5 x$ filing motion

-Caries removal
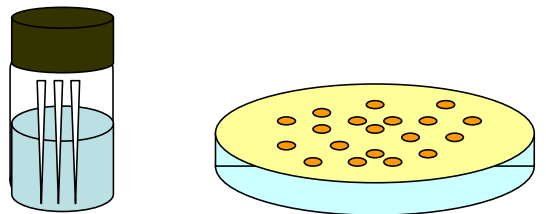

-Anaerobic culture for 1 week 
Figure 2: Post-Instrumentation Sample (S2)

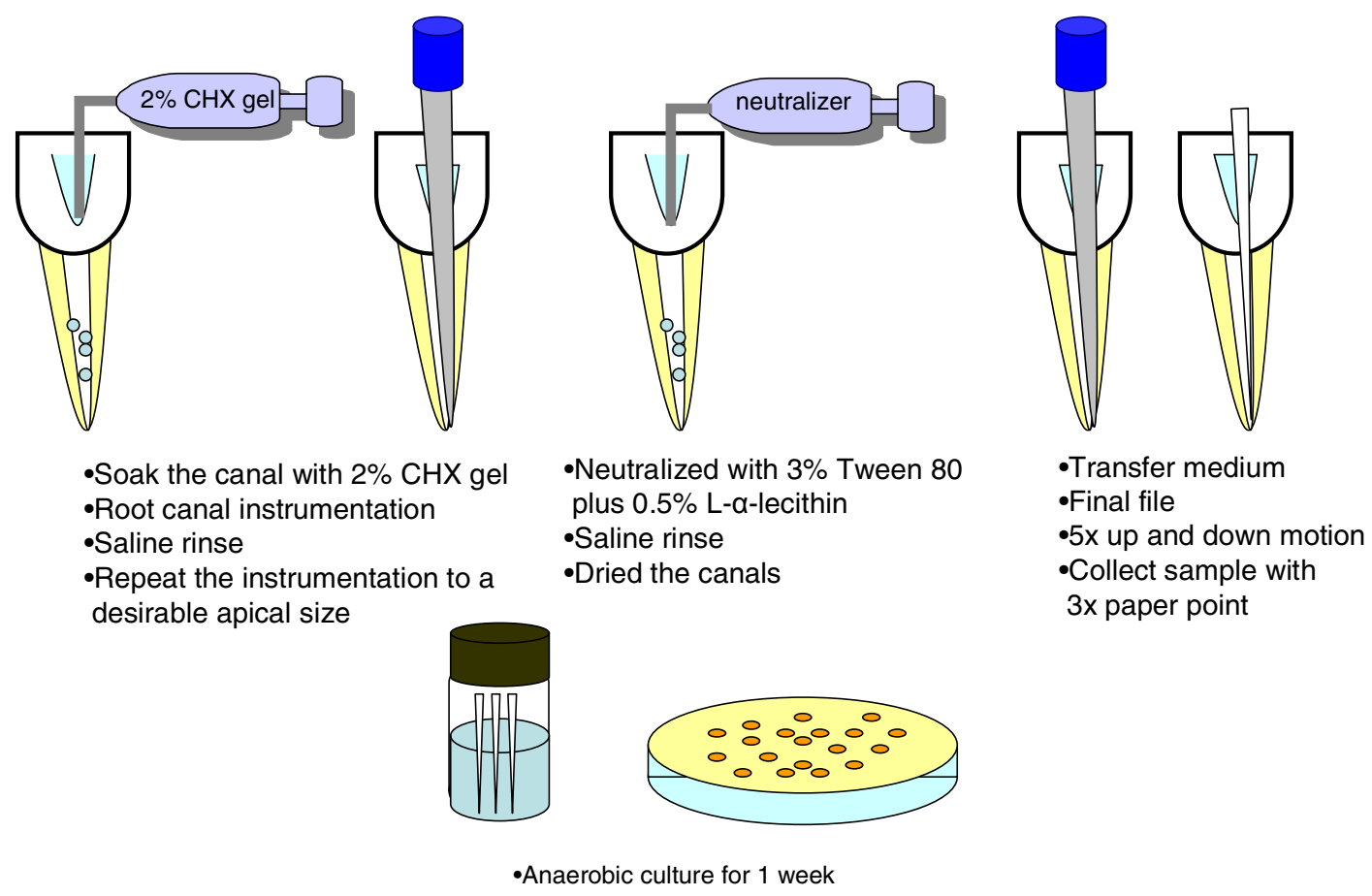


Figure 3: Post-Dressing Sample (S3)

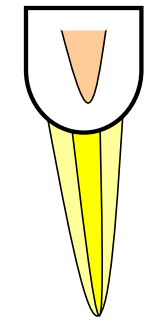

- $>2$ wk of mixture of $\mathrm{Ca}(\mathrm{OH}) 2+2 \% \mathrm{CHX}$ gel dressing

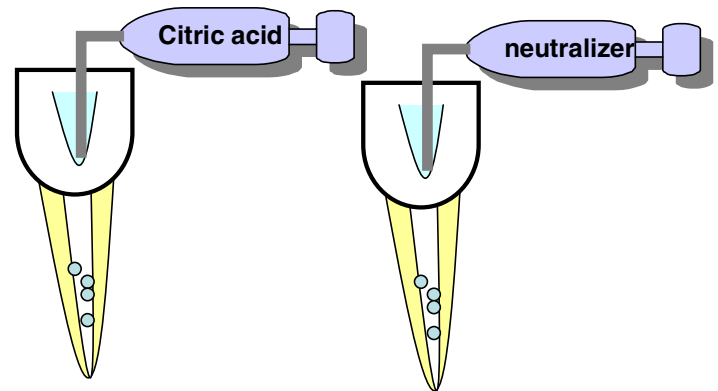

-Removed the intracanal dressing with saline - Neutralized with $0.5 \%$ citric acid and $3 \%$ Tween 80 plus $0.5 \%$ L-a-lecithin -Saline rinse

-Dried the canal
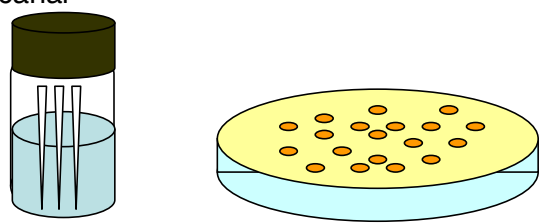

-Anaerobic culture for 1 week

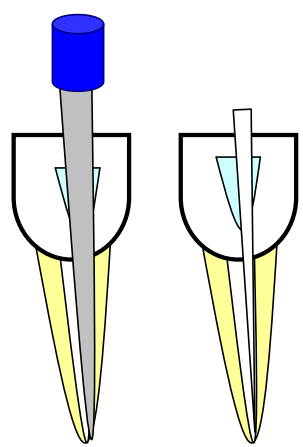

-Transfer medium -Final file

-5x up and down motion -Collect sample with 3x paper point 
The sample distribution at S1

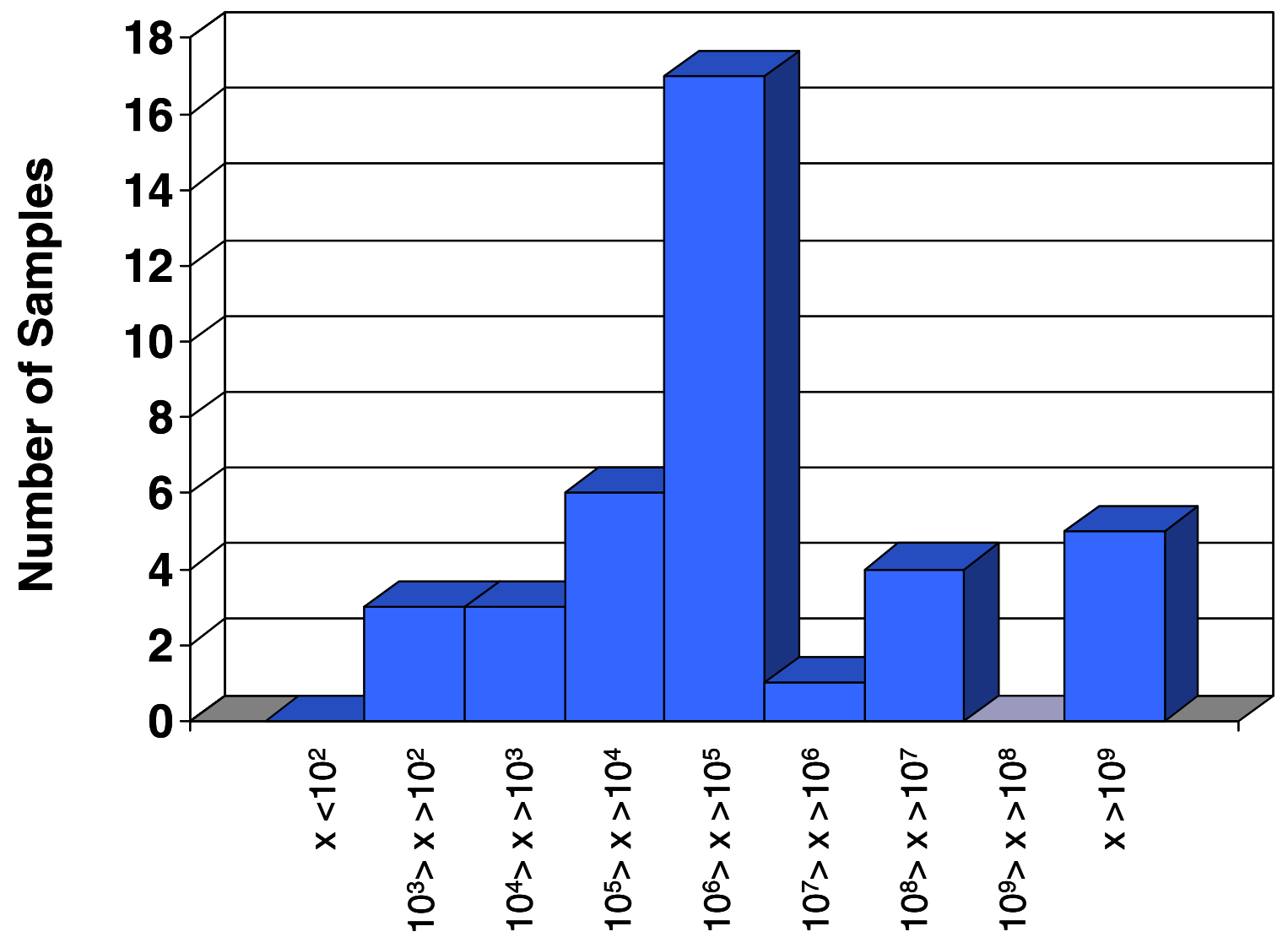

\section{Bacterial count (CFU/ml)}

Figure 4. The sample distribution at $\mathrm{S} 1 . \mathrm{x}$ represents the number of bacterial count $(\mathrm{CFU} / \mathrm{ml}), \mathrm{x}<10^{2}$ represents the samples that were below the limit of detection and considered as the negative culture. $x>10^{9}$ represents the samples that were too numerous to count. 


\section{The sample distribution at $\mathbf{S 2}$}

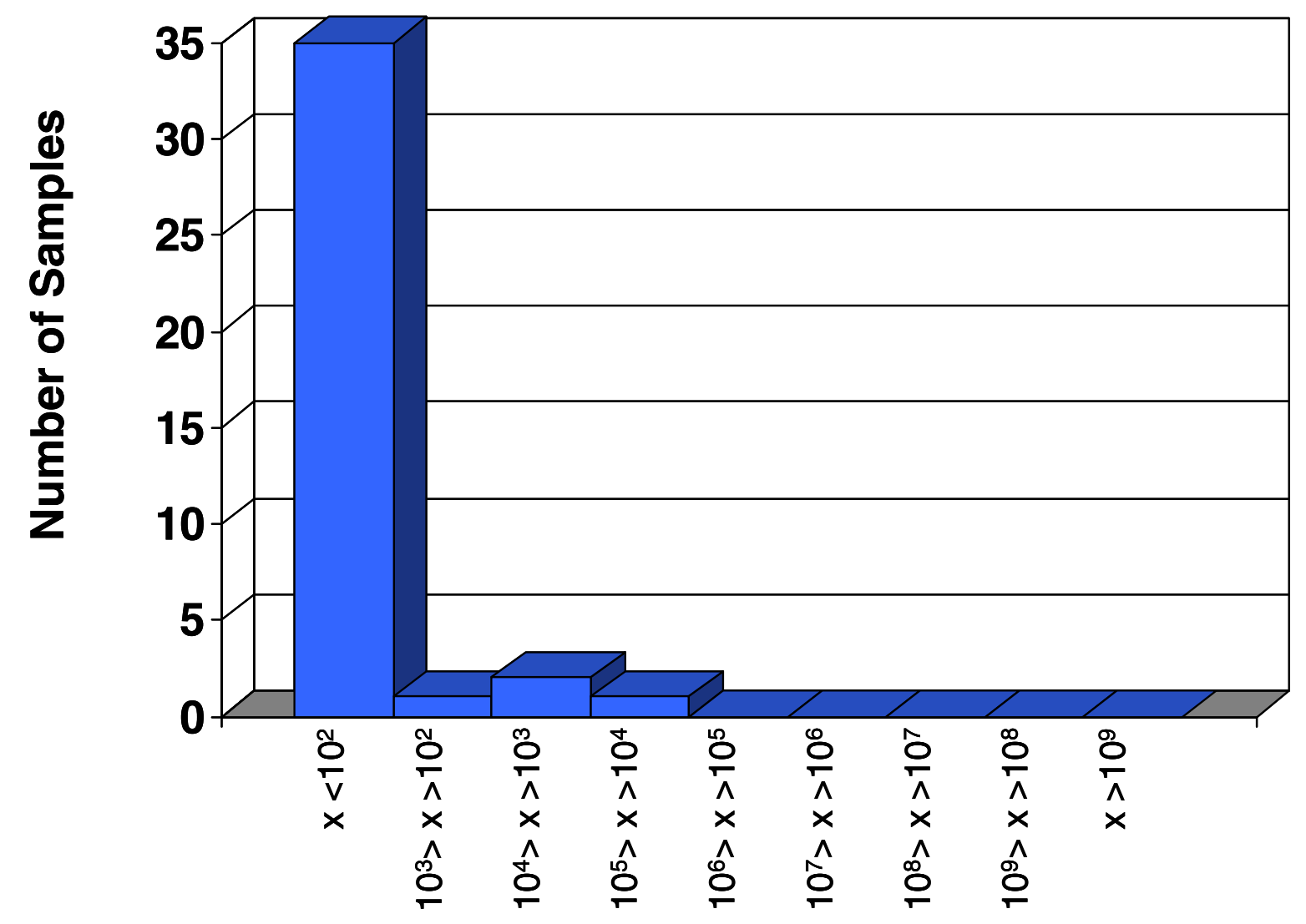

\section{Bacterial count (CFU/ml)}

Figure 5. The sample distribution at $\mathrm{S} 2$. $\mathrm{x}$ represents the number of bacterial count $(\mathrm{CFU} / \mathrm{ml}), \mathrm{x}<10^{2}$ represents the samples that were below the limit of detection and considered as the negative culture. $x>10^{9}$ represents the samples that were too numerous to count 


\section{The sample distribution at S3}

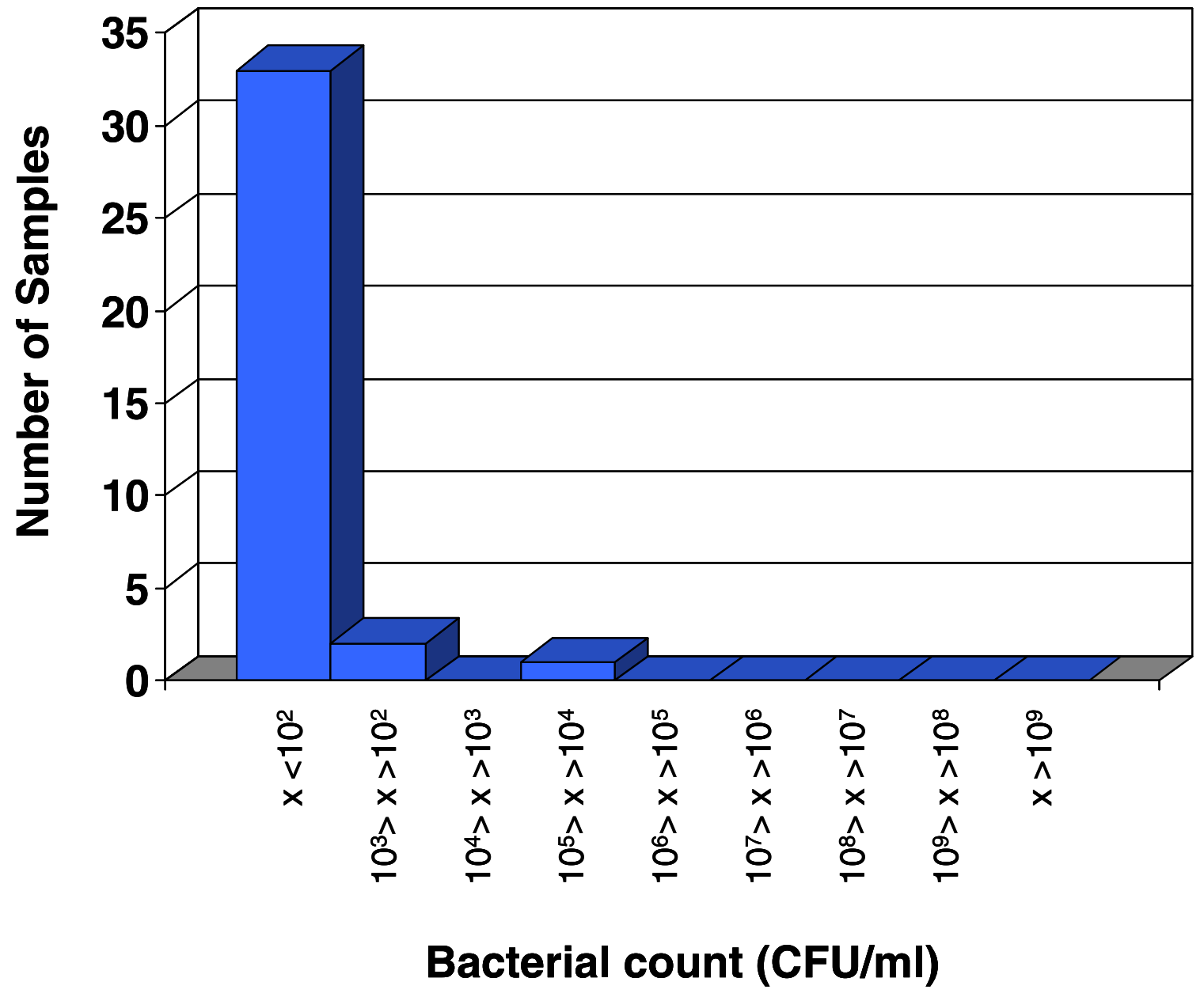

Figure 6. The sample distribution at $\mathrm{S} 3 . \mathrm{x}$ represents the number of bacterial count $(\mathrm{CFU} / \mathrm{ml}) . \mathrm{x}<10^{2}$ represents the samples that were below the limit of detection and considered as the negative culture. $x>10^{9}$ represents the samples that were too numerous to count 
Figure 7. Percentage of samples with positive culture

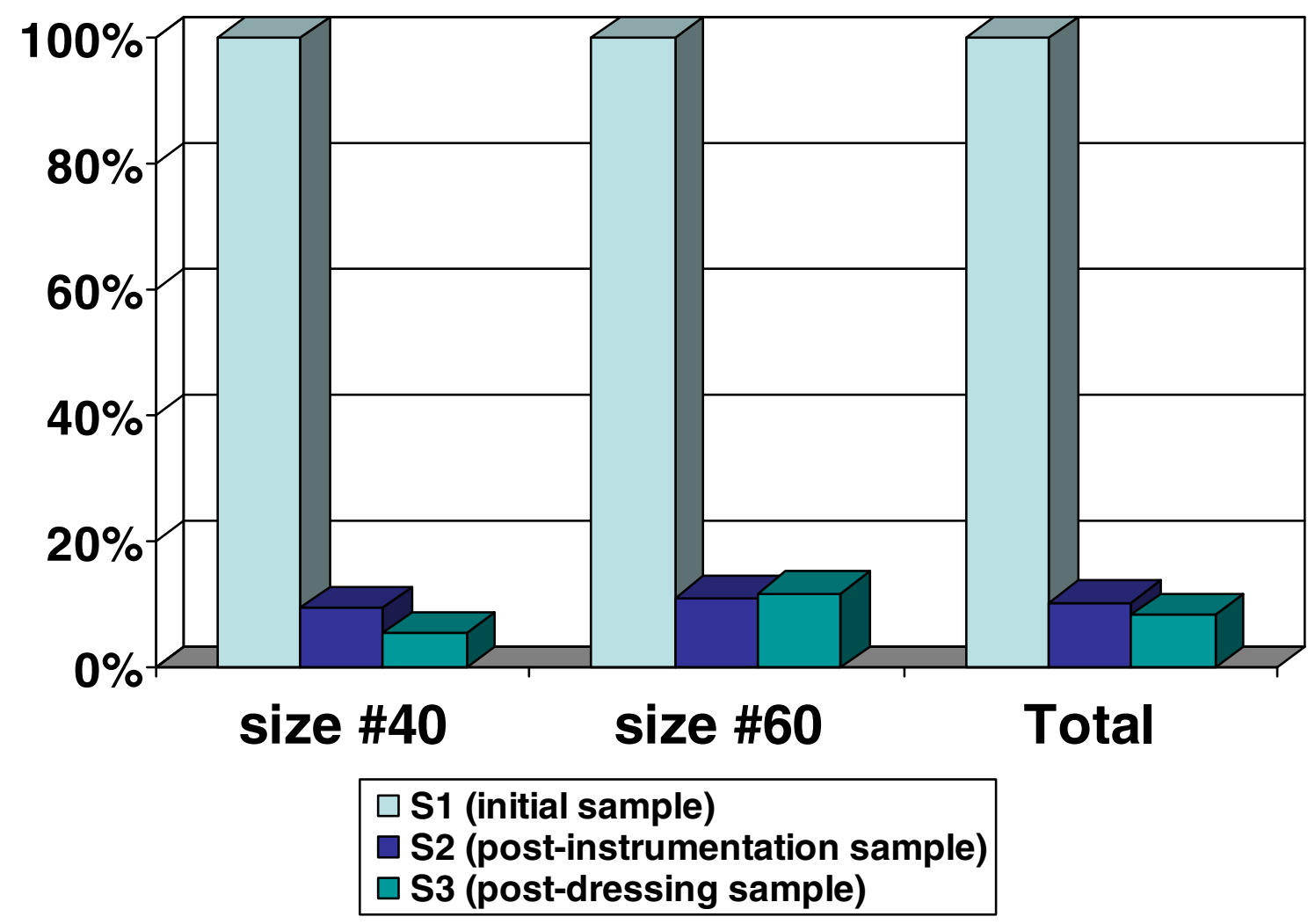


Figure 8. Comparison of percentage of canals with positive culture at different culturing points from selected studies

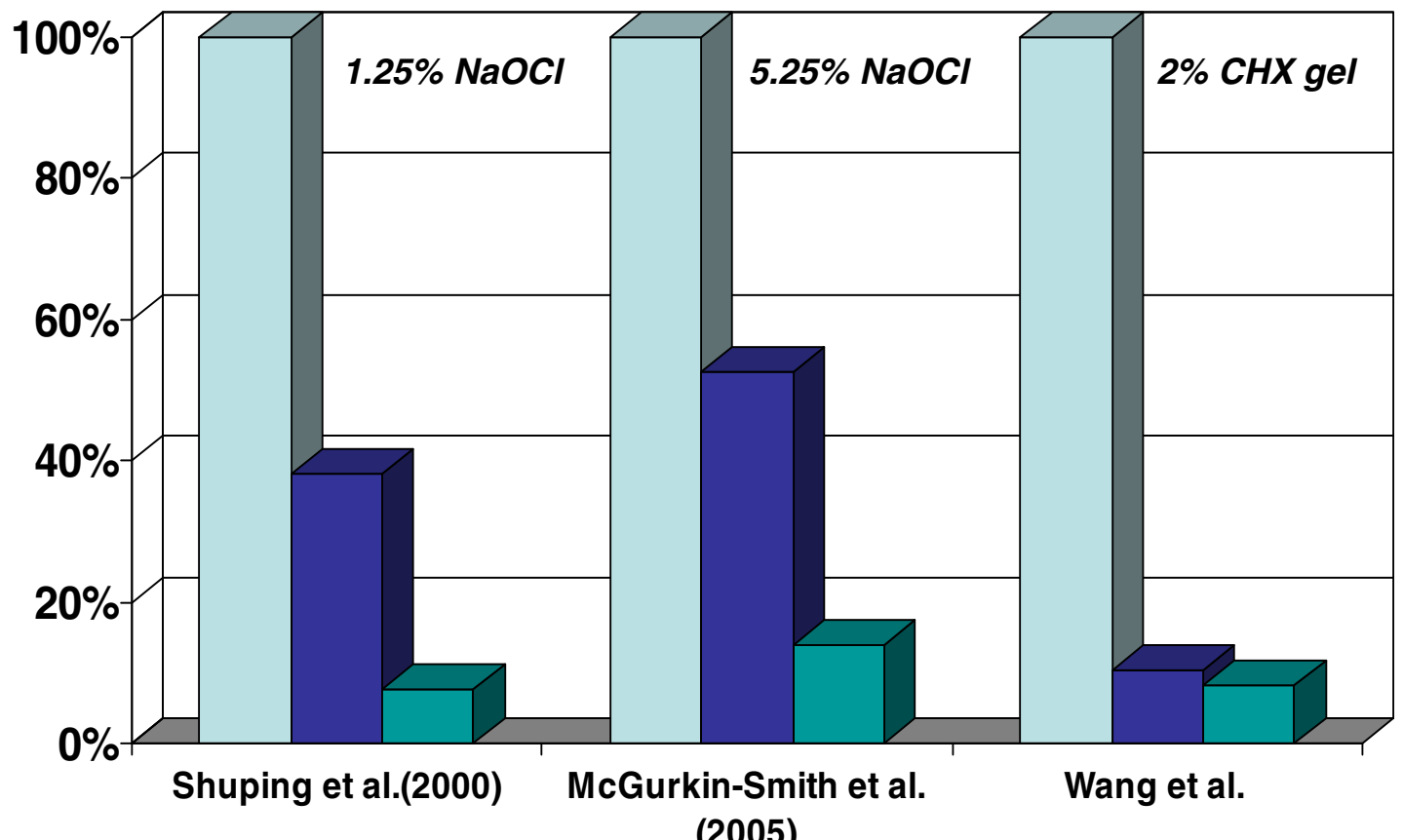

(2005)

$\square$ initial sample $\square$ post-instrumentation sample $\square$ post-dressing sample 


\section{REFERENCES}

Abramovich A, Goldberg F. The relationship of the root canal sealer to the dentine wall. An in vitro study using scanning electron microscope. J Br Endod Soc 1976; 9: 81-6.

Allard U, Nord CE, Sjoberg L, Stromberg T. Experimental infections with Staphylococcus aureus, Streptococcus sanguis, Pseudomonas aeruginosa, and Bacteroides fragilis in the jaws of dogs. Oral Surg Oral Med Oral Pathol. 1979; 48:454-62.

Ando N, Hoshino E. Predominant obligate anaerobes invading the deep layers or root canal dentine. Int Endod J. 1990; 23:20-7.

Aquilino SA, Caplan DJ. Relationship between crown placement and the survival of endodontically treated teeth. J Prosthet Dent. 2002; 87:256-63.

Barnes GW, Langeland K. Antibody formation in primates following introduction of antigens into the root canal. J Dent Res. 1966; 45:1111-4

Basrani B, Santos JM, Tjaderhane L, Grad H, Gorduysus O, Huang J, Lawrence HP, Friedman S. Substantive antimicrobial activity in chlorhexidine-treated human root dentin. Oral Surg Oral Med Oral Pathol Oral Radiol Endod 2002; 94:240-5

Barthel CR, Zimmer S, Trope M. Relationship of radiologic and histologic signs of inflammation in human root-filled teeth. J Endod 2004; 30:75-9

Baugh D, Wallace J. The role of apical instrumentation in root canal treatment: a review of the literature. J Endod 2005; 31:333-40

Baumgartner JC, Brown CM, Mader CL, Peters DD, Shulman JD. A scanning electron microscopic evaluation of root canal debridement using saline, sodium hypochlorite, and citric acid. J Endod 1984; 10:525-531

Baumgartner JC, Falkler WA. Reactivity of IgG from explant cultures of periapical lesions with implicated microorganisms. J Endod 1991; 17:207-12.

Baumgartner JC, Cuenin PR. Efficacy of several concentrations of sodium hypochlorite for root canal irrigation. J Endod. 1992; 18:605-12.

Baumgartner JC, Watts CM, Xia T. Occurrence of Candida albicans in infections of endodontic origin. J Endod. 2000; 26:695-8.

Baumgartner JC, Johal S, Marshall JG. Comparison of the antimicrobial efficacy of $1.3 \%$ $\mathrm{NaOCl} / \mathrm{BioPure} \mathrm{MTAD}$ to $5.25 \% \mathrm{NaOCl} / 15 \%$ EDTA for root canal irrigation. J Endod. 2007; 33:48-51 
Bender IB, Seltzer S. Roentgenographic and direct observation of experimental lesions in bone: I. 1961. J Endod. 2003; 29:702-6

Bender IB, Seltzer S. Roentgenographic and direct observation of experimental lesions in bone: II. 1961. J Endod. 2003; 29:707-12

Bergenholtz G, Lindhe J. Effect of experimentally induced marginal periodontitis and periodontal scaling on the dental pulp. J Clin Periodontol. 1978; 5:59-73.

Brynolf I. Histological and roentgenological study of periapical region of human upper incisors. Odontol. Revy 1967; 18: suppl. 11

Buckley M, Spangberg LS. The prevalence and technical quality of endodontic treatment in an American subpopulation. Oral Surg Oral Med Oral Pathol Oral Radiol Endod. 1995; 79:92-100

Burke GW Jr, Knighton HT. The localization of microorganisms in inflamed dental pulps of rats following bacteremia. J Dent Res. 1960; 39:205-14.

Byström A, Sundqvist G. Bacteriologic evaluation of the efficacy of mechanical root canal instrumentation in endodontic therapy. Scan. J Dent. Res. 1981; 89:321-328

Byström A, Sundqvist G. The antibacterial action of sodium hypochlorite and EDTA in 60 cases of endodontic therapy. Int Endod J. 1985; 18: 35-40

Byström A, Happonen RP, Sjögren U, Sundqvist G. Healing of periapical lesions of pulpless teeth after endodontic treatment with controlled asepsis. Endod Dent Traumatol 1987; 3:58-63

Caplan DJ, Weintraub JA. Factors related to loss of root canal filled teeth. J Public Health Dent. 1997;57:31-9.

Card SJ, Sigurdsson A, Ørstavik D, Trope M. The effectiveness of increased apical enlargement in reducing intracanal bacteria. J Endod. 2002; 28:779-83.

Chow TW. Mechanical effectiveness of root canal irrigation. J Endod. 1983; 9:475-9.

Chyun YS, Raisz LG. Stimulation of bone formation by prostaglandin E2. Prostaglandins. 1984; 27:97-103.

Coolidge E. The diagnosis and treatment of conditions resulting from diseased dental pulps. JADA 1919; 6:337-49

Cvek M, Nord CE, Hollender L. Antimicrobial effect of root canal debridement in teeth with immature root. A clinical and microbiologic study. Odontol Revy. 1976; 27:1-10. 
Czarnecki RT, Schilder H. Effect of experimentally induced marginal periodontitis and periodontal scaling on the dental pulp. J Clin Periodontol. 1978; 5:59-73.

Dahlen G. Immune response in rats against lipopolysaccharides of Fusobacterium nucleatum and Bacteroides oralis administered in the root canal. Scand J Dent Res. 1980; 88:122-9.

Dahlen G, Fabricius L, Holm SE, Moller AJ. Circulating antibodies after experimental chronic infection in the root canal of teeth in monkeys.Scand J Dent Res. 1982; 90:338-44.

Dakin HD. On the use of certain antiseptic substances in the treatment of infected wounds. Br Med J 1915; ii:318-20

Dalton BC, Ørstavik D, Phillips C, Pettiette M, Trope M. Bacterial reduction with nickeltitanium rotary instrumentation. J Endod 1998; 24:763-7

Dametto FR, Ferraz CC, de Almeida Gomes BP, Zaia AA, Teixeira FB, de Souza-Filho FJ. In vitro assessment of the immediate and prolonged antimicrobial action of chlorhexidine gel as an endododontic irrigant against Enterococcus faecalis. Oral Surg Oral Med Oral Pathol 2005; 99:768-72

Dammaschke T, Schneider U, Stratmann U, Yoo JM, Schafer E. Effect of root canal dressings on the regeneration of inflamed periapical tissue. Acta Odontol Scand. 2005; 63:143-52

Delany GM, Patterson SS, Miller CH, Newton CW. The effect of chlorhexidine gluconate irrigation on the root canal flora of freshly extracted necrotic teeth. Oral Surg Oral Med Oral Pathol. 1982; 53:518-23

Delivanis PD, Snowden RB, Doyle RJ. Localization of blood-borne bacteria in instrumented unfilled root canals. Oral Surg Oral Med Oral Pathol. 1981; 52:430-2.

Delivanis PD, Fan VS. The localization of blood-borne bacteria in instrumented unfilled and overinstrumented canals. J Endod. 1984; 11:521-4.

Dummer PM, Hicks R, Huws D. Clinical signs and symptoms in pulp disease. Int Endod J. $1980 ; 13: 27-35$.

Engström B, Frostell G. Experiences of bacteriological root canal control. Acta Odontol Scand. $1964 ; 22: 43-69$.

Ercan E, Ozekinci T, Atakul F, Gul K. Antibacterial activity of 2\% chlorhexidine gluconate and $5.25 \%$ sodium hypochlorite in infected root canal: in vivo study. J Endod 2004; 39: 846 
Ercan E, DalliM, Dulgergil CT. In vitro assessment of the effectiveness of chlorhexidine gel and calcium hydroxide paste with chlorhexidine against Enterococcus faecalis and Candida albicans. Oral Surg Oral Med Oral Pathol Oral Radiol Endod. 2006; 102:27-31

Espevik T, Waage A, Faxyaag A, Shalaby MR. Regulation of interleukin-2 and interleukin-6 production from T-cells: involvement of interleukin-1 beta and transforming growth factorbeta.Cell Immunol. 1990; 126:47-56.

Estrela CR, Estrela C, Reis C, Bammann LL, Pecora JD. Control of microorganisms in vitro by endodontic irrigants. Braz Dent J. 2003; 14:187-92

Evans MD, Baumgartner JC, Khemaleelakul SU, Xia T. Efficacy of calcium hydroxide: chlorhexidine paste as an intracanal medication in bovine dentin. J Endod 2003; 29:338-9

Fabricius L, Dahlén G, Öhman A, Möller AJ. Predominant indigenous oral bacteria isolated from infected root canals after varied times of closure. Scan J Dent Res 1982(a); 9:134-44

Fabricius L, Dahlén G, Holm SE, Möller AJ. Influence of combinations of oral bacteria on periapical tissues of monkeys. Scand J Dent Res. 1982(b); 90:200-6.

Farzaneh M, Abitbol S, Friedman S. Treatment outcome in endodontics: the Toronto study. Phases I and II: Orthograde retreatment. J Endod. 2004; 30:627-33

Ferraz CC, Figueiredo de Almeida Gomes BP, Zaia AA, Teixeira FB, de Souza-Filho FJ. In vitro assessment of the antimicrobial action and the mechanical ability of chlorhexidine gel as an endodontic irrigant. J Endod. 2001; 27:452-5

Filho M, Leonardo M, Silva L, Anibal F, Faccioli L. Inflammatory responses to different endodontic irrigating solutions. Int Endod J. 2002; 35: 735-9

Gier RE, Mitchell DF. Anachoretic effect of pulpitis. J Dent Res. 1968; 47:564-70.

Glick M, Trope M, Pliskin ME. Detection of HIV in the dental pulp of a patient with AIDS.J Am Dent Assoc. 1989; 119:649-50.

Goldman M, White RR, Moser CR, Tenca JI: A comparison of three methods of cleaning and shaping the root canal in vitro. J Endod 1988; 14: 7-12.

Gomes BPFA, Ferraz CCR, Vianna ME, Berver VB, Teixeira FB, Souza-Filho FJ. In vitro antimicrobial activity of several concentrations of sodium hypochlorite and chlorhexidine gluconate in the elimination of Enterococcus faecalis. Int Endod J 2001; 34:424-8

Gomes BP, Vianna ME, Sena NT, Zaia AA, Ferraz CC, de Souza Filho FJ. In vitro evaluation of the antimicrobial activity of calcium hydroxide combined with chlorhexidine gel used as intracanal medicament. Oral Surg Oral Med Oral Pathol Oral Radiol Endod. $2006 ; 102: 544-50$ 
Green TL, Walton RE, Taylor JK, Merrell P. Radiographic and histologic periapical findings of root canal treated teeth in cadaver. Oral Surg Oral Med Oral Pathol Oral Radiol Endod. 1997; 83:707-11.

Grossman LI, Meiman BW. Solution of pulp tissue by chemical agents. JADA 1941; 28:223-5

Gutiérrez JH, Herrera VR, Berg EH, Villena F, Jofré A. The risk of intentional dissolution of the smear layer after mechanical preparation of root canals. Oral Surg Oral Med Oral Pathol 1990; 70:96-108.

Haapasalo M, Ørstavik D. In vitro infection and disinfection of dentinal tubules. J Dent Res 1987; 66:1375-9.

Hermann BW. Calciumhydroxid als mittel zum behandel und füllungen von zahnwurzelkanälen. Med Diss V; Würzburg; 1920

Heling I, Steinberg D, Kenig S, Gavrilovich I, Sela MN, Friedman M. Efficacy of a sustained-release device containing chlorhexidine and $\mathrm{Ca}(\mathrm{OH})_{2}$ in preventing secondary infection of dentinal tubules. International Endodontic Journal 1992; 25:20-4

Hülsmann and Hahn W. Complications during root canal irrigation--literature review and case reports. Int Endod J. 2000; 33:186-93

Jeansonne MJ, White RR. A comparision of 2.0\% chlorhexidine gluconate and 5.25\% sodium hypochlorite as antimicrobial endodontic irrigants. J Endod 1994; 20:276-8

Kakehashi S., Stanley HR, Fitzgerald RJ. The effects of surgical exposures of dental pulps in germ-free and conventional laboratory rats. Oral Surg Oral Med Oral Pathol 1965; 20: 340-349

Kerekes K, Tronstad L. Long-term results of endodontic treatment performed with a standardized technique. J Endod 1979; 5: 83-90

Kho P, Baumgartner JC. A comparison of the antimicrobial efficacy of $\mathrm{NaOCl}$ /Biopure MTAD versus NaOCl/EDTA against Enterococcus faecalis. J Endod. 2006;32:652-5

Kuttler Y. Microscopic investigation of root apexes. J Am Dent Assoc. 1955; 50:544-52.

Kouvas V, Liolios E, Vassiliadis L, Parissis-Messimeris S, Boutsioukis A. Influence of smear layer depth of penetration of three endodontic sealers: an SEM study. Endod Dent Truamatol 1998; 14: 191-5 
Kvist T, Molander A, Dahlén G, and Reit C. Microbiological evaluation of one- and two-visit endodontic treatment of teeth with apical periodontitis: a randomized, clinical trial. J Endod 2004; 30: $572-576$

Law A, Messer H. An evidence-based analysis of the antibacterial effectiveness of intracanal medicaments. J Endod 2004; 30: 689-693

Langeland K, Rodrigues H, Dowden W. Periodontal disease, bacteria, and pulpal histopathology. Oral Surg Oral Med Oral Pathol. 1974; 37:257-70.

Love RM. Bacterial penetration of the root canal of intact incisor teeth after a simulated traumatic injury. Endod Dent Traumatol. 1996; 12:289-93.

Love RM, Jenkinson HF. Invasion of dentinal tubules by oral bacteria. Crit Rev Oral Biol Med 2002; 13:171-183.

Matsuo T, Nakanishi T, Ebisu S. Immunoglobulins in periapical exudates of infected root canals: correlations with the clinical findings of the involved teeth. Endod Dent Traumatol. $1995 ; 11: 95-9$.

Matsuo T, Shirakami T, Ozaki K, Nakanishi T, Yumoto H, Ebisu S. An immunohistological study of the localization of bacteria invading root pulpal walls of teeth with periapical lesions. J Endod. 2003; 29:194-200.

McComb D, Smith DC. A preliminary scanning electron microscopic study of root canals after endodontic procedures. J Endod 1975; 1: 238-42.

McDonnell G, Russell AD. Antiseptics and disinfectants: activity, action, and resistance. Clin Microbiol Rev. 1999; 12:147-79

McGurkin-Smith R, Trope M, Caplan D, Sigurdsson A. Reduction of intracanal bacteria using GT rotary Instrumentation, $5.25 \% \mathrm{NaOCl}$, EDTA, and $\mathrm{Ca}(\mathrm{OH})_{2}$. J Endod 2005; 21: 359-363

Miller WD. The micro-organisms of the human mouth. Philadelphia, 1980, White Dental

Molander A, Reit C, Dahlén G, Kvist T. Microbiological status of root-filled teeth with apical periodontitis. Int Endod J. 1998; 31:1-7.

Möller AJ. Microbiological examination of root canals and periapical tissues of human teeth. Methodological studies. Odontologisk Tidskrift 1966; 74(Suppl.): 1-380

Möller AJ, Fabricius L, Dahlén G, Öhman A, Heyden G. Influence on periradicular tissues of indigenous oral bacteria and necrotic pulp tissue in monkeys. Scan J Dent Res 1981; $89: 475-84$ 
Moorer WR, Wesselink PR. Factors promoting the tissue dissolving capability of sodium hypochlorite. Int Endod J. 1982; 15:187-96.

Mumford JM. Pain perception threshold on stimulating human teeth and the histological condition of the pulp. Br Dent J. 1967; 123:427-33.

Naenni N, Thoma K, Zehnder M. Soft tissue dissolution capacity of currently used and potential endodontic irrigants. J Endod. 2004; 30:785-7

Nagaoka S, Miyazaki Y, Liu HJ, Iwamoto Y, Kitano M, Kawagoe M. Bacterial invasion into dentinal tubules of human vital and nonvital teeth. J Endod. 1995; 21:70-3.

Nair PN. Pathogenesis of apical periodontitis and the causes of endodontic failures. Crit Rev Oral Biol Med. 2004; 15:348-81.

Oguntebi BR. Dentine tubule infection and endodontic therapy implications. Int Endod J. 1994; 27:218-22.

Okiji T, Morita I, Sunada I, Murota S. Involvement of arachidonic acid metabolites in increases in vascular permeability in experimental dental pulpal inflammation in the rat. Arch Oral Biol. 1989; 34:523-8.

Ørstavik D, Haapasalo M. Disinfection by endodontic irrigants and dressings of experimentally infected dentinal tubules. Endod Dent Traumatol. 1990; 6:142-9.

Ørstavik D, Kerekes K, Molven O. Effects of extensive apical reaming and calcium hydroxide dressing on bacterial infection during treatment of apical periodontitis: a pilot study. Int Endod J. 1991; 24: 1-7

Pallarés A, Faus V, Glickman GN. The adaptation of mechanically softened gutta-percha to the canal walls in the presence or absence of smear layer: a scanning electron microscopic study. Int Endod J 1995; 28: 266-9.

Pashley EL, Birdsong NL, Bowman K, Pashley DH. Cytotoxic effects of $\mathrm{NaOCl}$ on vital tissue. J Endod. 1985; 11:525-8.

Pashley DH, Depew DD. Effects of the smear layer, Copalite, and oxalate on microleakage. Oper Dent 1986;11: 95-105

Perez F, Rochd T, Lodter J-P, Calas P, Michel G. In vitro study of the penetration of three bacterial strains into root dentin. Oral Surg Oral Med Oral Pathol 1993; 76: 97-103.

Peters LB, Wesselink PR, Buijs JF, van Winkelhoff AJ. Viable bacteria in root dentinal tubules of teeth with apical periodontitis. J Endod 2001; 27: 76-81. 
Peters LB, Wesselink PR. Periapical healing of endodontically treated teeth in one and two visits obturated in the presence or absence of detectable microorganisms. Int Endod J. 2002; 35:660-7.

Podbielski A, Spahr A, Haller B. Additive antimicrobial activity of calcium hydroxide and chlorhexidine on common endodontic bacterial pathogens. J Endod 2003; 29:340-5

Pulver WH, Taubman MA, Smith DJ. Immune components in human dental periapical lesions. Arch Oral Biol. 1978; 23:435-43.

Rutala WA, Weber DJ. Uses of inorganic hypochlorite (bleach) in health-care facilities. Clin Microbiol Rev. 1997; 10:597-610.

Ram Z. Effectiveness of root canal irrigation. Oral Surg Oral Med Oral Pathol. 1977; 44:30612.

Ray HA, Trope M. Periapical status of endodontically treated teeth in relation to the technical quality of the root filling and the coronal restoration. Int Endod J. 1995; 28:12-8.

Reit C, Molander A, Dahlen G. The diagnostic accuracy of microbiologic root canal sampling and the influence of antimicrobial dressings. Endod Dent Traumatol. 1999; 15:278-83

Riccuci D. Apical limit of root canal instrumentation and obturation, part 1. Literature review. Int Endod J. 1998; 3:384-93.

Riccuci D, Langeland K. Apical limit of root canal instrumentation and obturation, part 2. A histological study. Int Endod J. 1998; 3:394-409.

Ringel AM, Patterson SS, Newton CW, Miller CH, Mülhern JM. In vivo evaluation of chlorhexidine gluconate solution and sodium hypochlorite solution as root canal irrigants. J Endod. 1982; 8:200-4

Robinson HBG, Boling LR: The anachoretic effect in pulpitis: bacteriologic studies. J Am Dental Assoc 1941; 28:268

Rosenthal S, Spangberg L, Safavi K. Chlorhexidine substantivity in root canal dentin. Oral Surg Oral Med Oral Pathol Oral Radiol Endod 2004; 98:488-92

Rubach WC, Mitchell DF. Periodontal disease, age, and pulp status. Oral Surg Oral Med Oral Pathol. 1965; 19:482-93.

Russell AD, Day MJ. Antibacterial activity of chlorhexidine. J Hosp Infect. 1993; 25:229-38

Safavi KE, Spangberg LS, Langeland K. Root canal dentinal tubule disinfection. J Endod. 1990; 16:207-10. 
Salzgeber RM, Brilliant JD. An in vivo evaluation of the penetration of an irrigating solution in root canals. J Endod. 1977; 3:394-8.

Schaeffer MA, White RR, Walton RE. Determining the optimal obturation length: a metaanalysis of literature. J Endod. 2005; 31:271-4.

Schilder H. Filling root canals in three dimensions.Dent Clin North Am. 1967: 723-44.

Schilder H. Cleaning and shaping the root canal. Dent Clin North Am. 1974; 18:269-96

Seltzer S, Bender IB, Ziontz M. The interrelationship of pulp and periodontal disease. Oral Surg Oral Med Oral Pathol. 1963; 16:1474-90

Seltzer S, Bender IB, Ziontz M. The dynamics of pulp inflammation: correlations between diagnostic data and actual histologic findings in the pulp. Oral Surg Oral Med Oral Pathol. $1963 ; 16: 846-71$

Seltzer S, Bender IB, Nazimov H, Sinai I. Pulpitis-induced interradicular periodontal changes in experimental animals. J Periodontol. 1967; 38:124-9.

Sen BH, Pi'kin B, Demirci T. Observation of bacteria and fungi in infected root canals and dentinal tubules by SEM. Endod Dent Traumatol 1995; 11: 6-9.

Shuping GB, Ørstavik D, Sigurdsson A, Trope M. Reduction of intracanal bacteria using nickel-titanium rotary instrumentation and various medications. J Endod 2000; 26: 751-755

Shipper G., Ørstavik D, Teixeira FB, and Trope M. An evaluation of microbial leakage in roots filled with a thermoplastic synthetic polymer-based root canal filling material (Resilon). J Endod 2004; 30: 342-347

Siqueira JF Jr, de Uzeda M, Fonseca MEF. A scanning electron microscopic evaluation of in vitro dentinal tubules penetration by selected anaerobic bacteria. J Endod 1996; 22: 30810 .

Siqueira JF Jr, da Silva CH, Cerqueira M das D, Lopes HP, de Uzeda M. Effectiveness of four chemical solutions in eliminating Bacillus subtilis spores on gutta-percha cones. Endod Dent Traumatol. 1998; 14:124-6.

Siqueira JF Jr, Lopes HP. Mechanisms of antimicrobial activity of calcium hydroxide: a critical review. Int Endod J. 1999; 32:361-9.

Siqueira JF Jr, Lima KC, Magalhaes FA, Lopes HP, de Uzeda M. Mechanical reduction of the bacterial population in the root canal by three instrumentation techniques. $\mathrm{J}$ Endod. $1999 ; 25: 332-5$. 
Siqueira JF Jr., Rocas IN, Alves FR, Campos LC. Periradicular status related to the quality of coronal restorations and root canal fillings in a Brazilian population. Oral Surg Oral Med Oral Pathol Oral Radiol Endod. 2005; 100:369-74

Siqueira JF Jr, Rocas IN, Favieri A, Lima KC. Chemomechanical reduction of the bacterial population in the root canal after instrumentation and irrigation with 1\%, 2.5\%, and 5.25\% sodium hypochlorite. J Endod. 2000; 26:331-4

Sirén EK, Haapasalo MP, Waltimo TM, Ørstavik D. In vitro antibacterial effect of calcium hydroxide combined with chlorhexidine or iodine potassium iodide on Enterococcus faecalis. Eur J Oral Sci. 2004; 112:326-31

Sjögren U, Hagglund B, Sundqvist G, Wing K. Factors affecting the long-term results of endodontic treatment. J Endod 1990; 16:498-504

Sjögren U, Figdor D, Spangberg L, Sundqvist G. The antimicrobial effect of calcium hydroxide as a short-term intracanal dressing. Int Endod J. 1991; 24, 119-125

Sjögren U, Figdor D, Persson S, Sundqvist G. Influence of infection at the time of root filling on the outcome of endodontic treatment of teeth with apical peridontitis. Int Endod J. 1997; $30,297-306$

Sorensen JA, Martinoff JT. Intracoronal reinforcement and coronal coverage: a study of endodontically treated teeth. J Prosthet Dent. 1984; 51:780-4

Sorensen JA, Martinoff JT. Endodontically treated teeth as abutments. J Prosthet Dent. 1985; 53:631-6.

Spangberg L, Engstrom B, Langeland K. Biologic effects of dental materials. 3. Toxicity and antimicrobial effect of endodontic antiseptics in vitro. Oral Surg Oral Med Oral Pathol. 1973; 36:856-71.

Stashenko P, Dewhirst FE, Peros WJ, Kent RL, Ago JM. Synergistic interactions between interleukin 1, tumor necrosis factor, and lymphotoxin in bone resorption. J Immunol. 1987; 138:1464-8.

Stashenko P, Yu SM. T helper and T suppressor cell reversal during the development of induced rat periapical lesions. J Dent Res. 1989; 68:830-4

Stashenko P, Wang CY, Tani-Ishii N, Yu SM. Pathogenesis of induced rat periapical lesions. Oral Surg Oral Med Oral Pathol. 1994; 78:494-502.

Stashenko P, Wang CY, Riley E, Wu Y, Ostroff G, Niederman R. Reduction of infectionstimulated periapical bone resorption by the biological response modifier PGG glucan. $\mathrm{J}$ Dent Res. 1995; 74:323-30 
Stashenko P, Teles R, D’Souza R. Periapical inflammatory responses and their modulation. Crit Rev Oral Biol Med. 1998; 9:498-521.

Stern MH, Dreizen S, Mackler BF, Selbst AG, Levy BM. Quantitative analysis of cellular composition of human periapical granuloma. J Endod. 1981; 7:117-22.

Stern MH, Mackler BF, Dreizen S. A quantitative method for the analysis of human periapical inflammation. J Endod. 1981; 7:70-4.

Stoll R, Betke K, Stachniss V. The influence of different factors on the survival of root canal fillings: a 10-year retrospective study. J Endod. 2005; 31:783-90.

Stringberg L. The dependence of the results of pulp therapy of certain factors. An analytical study based on radiographic and clinical follow-up examinations. Acta Odontol Scan 1956; 14 (supplement 21)

Stuart CH, Schwartz SA, Beeson TJ, Owatz CB. Enterococcus faecalis: its role in root canal treatment failure and current concepts in retreatment. J Endod. 2006; 32:93-8

Sundqvist G. Bacteriological studies of necrotic dental pulps. Umea University Odontological Dissertations No. 7, University of Umea, Sweden; 1976

Sundqvist G, Figdor D, Persson S. Microbiologic findings of teeth with failed endodontic treatment and the outcome of conservative re-treatment. Oral Surg. 1998; 85:86-93

Sundqvist G. Ecology of the root canal flora. J Endod 1992; 18:427-30.

Tani-Ishii N, Wang CY, Stashenko P. Immunolocalization of bone-resorptive cytokines in rat pulp and periapical lesions following surgical pulp exposure. Oral Microbiol Immunol. $1995 ; 10: 213-9$.

Taylor JK, Jeansonne BG, Lemon RR. Coronal leakage: effects of smear layer, obturation technique, and sealer. J Endod 1997; 23: 508-12

Thé SD, Maltha JC, Plasschaert AJ. Reactions of guinea pig subcutaneous connective tissue following exposure to sodium hypochlorite. Oral Surg Oral Med Oral Pathol. 1980; 49:460-6.

Tidmarsh BG. Acid-cleansed and resin-sealer root canals. J Endod 1978; 4: 117-121.

Timpawat S, Vongsavan N, Messer HH. Effect of removal of the smear layer on apical microleakage. J Endod 2001; 27: 351-3.

Torabinejad M, Bakland LK. An animal model for the study of immunopathogenesis of periapical lesions. J Endod. 1978; 4:273-7. 
Torabinejad M, Kettering JD. Identification and relative concentration of $\mathrm{B}$ and $\mathrm{T}$ lymphocytes in human chronic periapical lesions.J Endod. 1985; 1:122-5.

Torabinejad M, Eby WC, Naidorf IJ. Inflammatory and immunological aspects of the pathogenesis of human periapical lesions. J Endod. 1985; 11:479-88.

Torabinejad M, Kiger RD. A histologic evaluation of dental pulp tissue of a patient with periodontal disease. Oral Surg Oral Med Oral Pathol. 1985; 59:198-200.

Torabinejad M, Handysides R, Khademi AA, Bakland L K. Clinical implications of the smear layer in endodontics: A review. Oral Surg Oral Med Oral Pathol Oral Radiol Endod 2002; 94: 658-66.

Torabinejad M, Khademi AA, Babagoli J, et al. A new solution for the removal of the smear layer. J Endod 2003(a); 29: 170-175.

Torabinejad M, Cho Y, Khademi AA, Bakland LK, Shabahang S. The effect of various concentration of sodium hypochlorite on the ability of MTAD to remove the smear layer. J Endod 2003(b); 29: 233-239.

Tronstad L, Barnett F, Riso K, Slots J. Extraradicular endodontic infections. Endod Dent Traumatol. 1987; 3:86-90.

Tronstad L, Asbjornsen K, Doving L, Pedersen I, Eriksen HM. Influence of coronal restorations on the periapical health of endodontically treated teeth. Endod Dent Traumatol. 2000; 16:218-21.

Trope M, Delano EO, Ørstavik D. Endodontic treatment of teeth with apical periodontitis: single vs. multivisit treatment. J Endod. 1999; 25: 345-50

Vianna ME, Gomes BP, Berber VB, Zaia AA, Ferraz CC, de Souza-Filho FJ. In vitro evaluation of the antimicrobial activity of chlorhexidine and sodium hypochlorite. Oral Surg Oral Med Oral Pathol Oral Radiol Endod. 2004; 97:79-84

Vianna ME, Horz HP, Gomes BP, Conrads G. In vivo evaluation of microbial reduction after chemo-mechanical preparation of human root canals containing necrotic pulp tissue. Int Endod J. 2006; 39:484-492

Vire DE. Failure of endodontically treated teeth: classification and evaluation. J Endod. $1991 ; 17: 338-42$.

Wahl SM. Transforming growth factor beta: the good, the bad, and the ugly. J Exp Med. 1994; 180:1587-90.

Waltimo TM, Siren EK, Torkko HL, Olsen I, Haapasalo MP. Fungi in therapy-resistant apical periodontitis. Int Endod J. 1997; 30:96-101. 
Waltimo T, Trope M, Haapasalo M, Orstavik D. Clinical efficacy of treatment procedures in endodontic infection control and one year follow-up of periapical healing. J Endod. 2005; 31:863-6

Wang CY, Stashenko P. Characterization of bone-resorbing activity in human periapical lesions. J Endod. 1993; 19:107-11.

Wang CY, Stashenko P. The role of interleukin-1 alpha in the pathogenesis of periapical bone destruction in a rat model system. Oral Microbiol Immunol. 1993; 8:50-6.

Wang CY, Tani-Ishii N, Stashenko P. Bone-resorptive cytokine gene expression in periapical lesions in the rat. Oral Microbiol Immunol. 1997; 12:65-71.

Weiger R, de Lucena J, Decker HE, Lost C. Vitality status of microorganisms in infected human root dentine. Int Endod J. 2002; 35:166-71.

Weiger R, Rosendahl R, Lost C. Influence of calcium hydroxide intracanal dressings on the prognosis of teeth with endodontically induced periapical lesions. Int Endod J. 2000; 33:219-26

Weine FS. Initiating endodontic therapy in posterior teeth. Part II. Maxillary molars. Compend Contin Educ Dent. 1982; 3:455-64

White R, Goldman M, Peck S-L. The influence of the smeared layer upon dentinal tubule penetration by plastic filling materials. J Endod 1984; 10:558-62.

Yamada RS, Armas A, Goldman M, Lin PS. A scanning electron microscopic comparison of a high volume final flush with several solutions: Part 3. J Endod 1983; 9: 137-142.

Yamasaki M, Kumazawa M, Kohsaka T, Nakamura H, Kameyama Y. Pulpal and periapical tissue reactions after experimental pulpal exposure in rats. J Endod. 1994 ; 20:13-7.

Yesilsoy C, Whitakers E, Cleveland D, Phillips E, Trope M. Antimicrobial and toxic effects of established and potential root canal irrigants. J Endod. 1995; 21:513-5.

Yu SM, Stashenko P. Identification of inflammatory cells in developing rat periapical lesions. J Endod. 1987; 13:535-40.

Zamany A, Spangberg LS. An effective method of inactivating chlorhexidine. Oral Surg Oral Med Oral Pathol Oral Radiol Endod. 2002; 93:617-20

Zeldow BI, Ingle JI. Correlation of the positive culture to the prognosis of endodontically treated teeth: a clinical study. J Am Dent Assoc. 1963; 66:9-13. 
Zehnder M, Kosicki D, Luder H, Sener B, Waltimo T. Tissue-dissolving capacity and antibacterial effect of buffered and unbuffered hypochlorite solutions. Oral Surg Oral Med Oral Pathol Oral Radiol Endod. 2002; 94:756-62.

Zerella JA, Fouad AF, Spangberg LS. Effectiveness of a calcium hydroxide and chlorhexidine digluconate mixture as disinfectant during retreatment of failed endodontic cases. Oral Surg Oral Med Oral Pathol Oral Radiol Endod 2005; 100:756-61 